\title{
Immunomodulatory Effects of Diet and Nutrients in Systemic Lupus Erythematosus (SLE): A Systematic Review
}

\author{
Md Asiful Islam ${ }^{1 *}$, Shahad Saif Khandker ${ }^{2}$, Przemysław J. Kotyla ${ }^{3}$ and Rosline Hassan ${ }^{1}$ \\ ${ }^{1}$ Department of Haematology, School of Medical Sciences, Universiti Sains Malaysia, Kubang Kerian, Malaysia, ${ }^{2}$ Department \\ of Biochemistry and Molecular Biology, Jahangirnagar University, Dhaka, Bangladesh, ${ }^{3}$ Department of Internal Medicine, \\ Rheumatology and Clinical Immunology, Medical Faculty in Katowice, Medical University of Silesia, Katowice, Poland
}

\section{OPEN ACCESS}

Edited by:

Susu M. Zughaier,

Qatar University, Qatar

Reviewed by:

Jillian M. Richmond,

University of Massachusetts Medical

School, United States

Melissa Anne Cunningham,

Medical University of South Carolina,

United States

*Correspondence:

Md Asiful Islam

asiful@usm.my;

ayoncx70@yahoo.com

Specialty section:

This article was submitted to Autoimmune and Autoinflammatory

Disorders,

a section of the journal

Frontiers in Immunology

Received: 25 June 2019

Accepted: 05 June 2020

Published: 22 July 2020

Citation:

Islam MA, Khandker SS, Kotyla PJ

and Hassan R (2020)

Immunomodulatory Effects of Diet and

Nutrients in Systemic Lupus

Erythematosus (SLE): A Systematic

Review. Front. Immunol. 11:1477.

doi: 10.3389/fimmu.2020.01477
Systemic lupus erythematosus (SLE) is an autoimmune disease characterized by multiple organ involvement, including the skin, joints, kidneys, lungs, central nervous system and the haematopoietic system, with a large number of complications. Despite years of study, the etiology of SLE remains unclear; thus, safe and specifically targeted therapies are lacking. In the last 20 years, researchers have explored the potential of nutritional factors on SLE and have suggested complementary treatment options through diet. This study systematically reviews and evaluates the clinical and preclinical scientific evidence of diet and dietary supplementation that either alleviate or exacerbate the symptoms of SLE. For this review, a systematic literature search was conducted using PubMed, Scopus and Google Scholar databases only for articles written in the English language. Based on the currently published literature, it was observed that a low-calorie and low-protein diet with high contents of fiber, polyunsaturated fatty acids, vitamins, minerals and polyphenols contain sufficient potential macronutrients and micronutrients to regulate the activity of the overall disease by modulating the inflammation and immune functions of SLE.

Keywords: diet, nutrients, autoimmune diseases, systemic lupus erythematosus (SLE), polyunsaturated fatty acids, vitamins, minerals, polyphenols

\section{INTRODUCTION}

Systemic lupus erythematosus (SLE), an autoimmune disease, is characterized by abnormal inflammatory responses due to complex, aberrant humoral and cellular immune responses. The pathogenesis of SLE is largely unknown; however, data from the literature suggest that manifestation of this disease is the result of several environmental, hormonal, and nutritional factors that, in predisposed subjects, contribute to impaired cellular, and humoral immune responses (1-3). Accordingly, the presence of autoantibodies is nearly universal among patients with SLE. Indeed, having antinuclear antibodies specifically against double-stranded DNA (dsDNA) is a hallmark classification criterion for SLE; this and other clinical and immunological criteria must be satisfied for SLE classification as proposed by the European League Against Rheumatism and American College of Rheumatology (4). Autoantibodies also contribute to the synthesis of multiple immune complexes and exert direct cytotoxic effects. As a result, SLE affects the whole body with no system spared; finally, damage occurs in multiple organs including the kidneys, central nervous system (CNS), skin, joints and haematopoietic system $(5,6)$. Although SLE 
represents a prototypical autoimmune disorder, its prevalence is relatively low, estimated between 6.5 and 178.0 per 100,000 people, with an incidence ranging from 0.3 to 23.7 per 100,000 people per year (7).

The contribution of lifestyle-associated factors is still a matter of controversy in SLE; however, dietary habits and dietaryrelated microbiome composition are receiving more attention from researchers $(8,9)$. Indeed, some SLE-related clinical features are associated with nutrition; perhaps not as an aetiological factor but as a clinical repercussion (10). Thus, SLE represents a mosaic of metabolic changes and mineral and vitamin deficiencies superimposed by the systemic presentation of arthritis, nephritis, vascular events and organ damage to the heart, CNS, kidneys, and skin, which contribute to increases in the morbidity and mortality of these patients $(6,11,12)$. In the last two decades, many clinical, and preclinical studies have investigated the impact of diet and nutrients on SLE inflammatory response and disease activity. This has become an important highlighted topic and remains under investigation by many researchers. Nutritional therapy including restrictions on carbohydrate and protein and the use of nutritional supplements (i.e., vitamins, minerals and polyphenols) is a promising way to control inflammatory responses in $\operatorname{SLE}(8,13)$. Nutritional supplements may exert potentially prophylactic effects with fewer or no side effects than those of the classic pharmacological therapies besides reducing co-morbidities and improving the quality of life of patients with SLE.

As a broad range of evidence has demonstrated that some diets and nutrients have antioxidant, anti-inflammatory and immunomodulatory effects on immunoinflammatory diseases, the present study evaluates the impact of diet and nutrients on SLE based on the existing in vivo studies in animal models and human subjects.

\section{METHODS: SEARCH STRATEGY}

A systematic search strategy was developed by combining the terms SLE, "Systemic lupus erythematosus," lupus, food, nutrient*, diet, intake, antioxidant*, nutrition*, benefit*, nutrition*, physicochemical, dietary, bioactive, composition, supplement*, vitamin*, mineral*, phenol*, "olive oil," and curcumin, where quotations represented an exact term and an asterisk $\left(^{*}\right)$ denoted a root word or wildcard term. PubMed, Scopus, and Google Scholar electronic databases were searched combining the appropriate keywords with Boolean logical operators "AND" and "OR" using "Advanced" and "Expert" search options (Appendix). Only English-language articles were searched. There was no year restriction, and the final systematic search was conducted on 22 December 2019. Review articles, non-English articles, errata, letters, comments, editorials, and duplicate articles among different databases were excluded. Duplicate studies that resulted from different electronic databases were removed and managed by EndNote software (version X8). Study selection methodology is illustrated in Figure 1.

\section{MACRONUTRIENTS}

Macronutrients represent the group of environmental substances widely used by organisms for vital processes such as growth, body development, and bodily functions. Several theories have described the effects of macronutrient- or macronutrient-derived molecules including glucose, amino acids, and fatty acids on body weight regulation, maintenance of homeostasis, and the immune response.

\section{Carbohydrates}

Carbohydrates are among the macronutrients that provide energy and, when consumed in excess, contribute to increased energy storage and subsequent weight gain. Although there is no clear evidence that altering the proportion of total carbohydrate in the diet is an important determinant of energy intake, nutritional imbalance, and excess carbohydrate dietary intake have been suggested as risk factors that exacerbate clinical manifestations of several autoimmune diseases such as rheumatoid arthritis and SLE (14). Obesity is a well-known risk factor for low-grade inflammation characterized by activation of several pathways involved in the expression of inflammatory cytokines such as tumor necrosis factor-alpha (TNF- $\alpha$ ) and interleukin (IL)-6. Activation of these proinflammatory pathways significantly contributes to the perpetuation of the inflammatory response, which are at least partly responsible for the severe co-morbidities seen in SLE patients (15). Indeed, patients with SLE are characterized by a high-risk of developing metabolic syndrome, insulin resistance and type 2 diabetes mellitus (T2DM) (16), which can contribute to increased risk of developing cardiovascular co-morbidities, a leading cause of premature death in SLE patients (17).

Indeed, several studies have shown that up to $35 \%$ of SLE patients are overweight and $39 \%$ are obese, and these patients are characterized by a higher concentration of inflammatory markers including C-reactive protein (CRP) $(18,19)$. Recent studies have suggested that obesity is associated independently with SLE disease activity $(20,21)$. Corticosteroids remain the first choice of treatment for SLE, but their administration is linked to excess weight gain and the development of corticosteroid-induced diabetes. Obesity was detected as an independent risk factor in worsening the functional capacity, fatigue, and inflammation status of patients with SLE (20, 22-24).

\section{Mouse Models}

Mouse models provide excellent insight into the pathogenesis of SLE and the observation of dietary-induced changes. Notably, the restriction of calorie intake leads to substantial changes in the immune response. For example, in a study with a lupus-prone mouse model (NZB/NZW F1), calorie intake restriction effectively delayed the onset of proteinuria and significantly decreased serum levels of anti-dsDNA antibodies. Calorie restriction also had a significant impact on the Bcell population, resulting in a reduction of their frequency and activity. Parallel to this, a decline in $\mathrm{CD}^{+} \mathrm{T}$ cells and a higher proportion of naïve $\mathrm{CD}^{+}$and $\mathrm{CD} 8^{+} \mathrm{T}$ cells have been observed (25). This finding is of special importance as it 


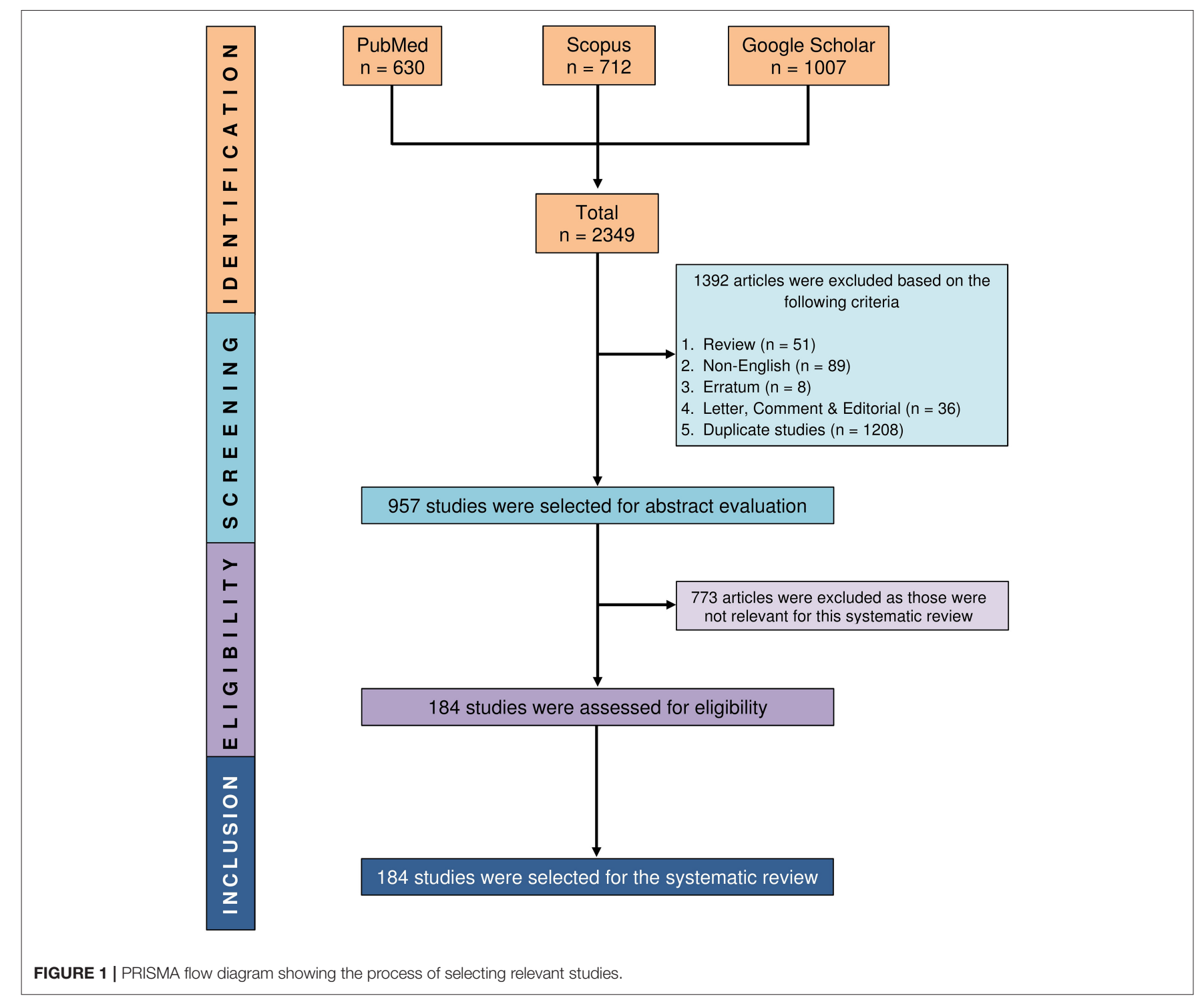

shows the direct impact of calorie restriction on B-cell and Tcell compartments, key immunocompetent cell compartments involved directly in SLE pathogenesis $(26,27)$. In another SLE-prone mouse model, when a $40 \%$ calorie-restricted diet was provided, B:T cell and $\mathrm{CD}^{+}: \mathrm{CD}^{+}$T-cell ratios were significantly lowered compared with the control group (28). This suggests a decline in the predominance of abnormally activated $\mathrm{T}$ cells and regulatory $\mathrm{T}$ (Treg) cells that potentially reduces disease activity.

The impact of calorie intake on autoimmune system functioning is not restricted to immune executive cells. At the end of the last century, Troyer et al. (29) showed that a calorierestricted diet was successful in modulating the key inflammatory ligand platelet-derived growth factor (PDGF) subunit A and the thrombin receptor, resulting in the suppression of murine lupus nephritis. Quite recently, the direct mechanism of this finding has been explained, elucidating the role of PDGF as a growth factor that regulates cell proliferation and is responsible for mesangial proliferation, periostin formation and progressive glomerulosclerosis (30).

Less is known about the humoral response in this regard. The influence of calorie restriction on the expression of main cytokines and synthesis of immunoglobulin (Ig)G has been tested in NZB/NZW F1 mice. In the study, reduced calorie intake contributed to the reduction of interferon (IFN)- $\gamma, I L-10$, and $I L$ 12 mRNA expression besides the reduction of IgG secretion in the submandibular glands (31).

\section{Human Study}

During the last several decades, the prevalence of excess body weight has increased rapidly worldwide and is now recognized as a main public health crisis (32). Obesity has a strong impact on organism functioning and is linked to the development of all diseases of civilization, including metabolic syndrome, atherosclerosis and T2DM. Strong evidence also links obesity to many autoimmune disorders including $\operatorname{SLE}(8,33,34)$. Obesity 
in SLE patients is associated with a poorer outcome, higher disease activity and higher cumulative organ damage $(34,35)$. Therefore, the importance of prevention and treatment of obesity is widely acknowledged. Unfortunately, these recommendations are chiefly driven from cross-population studies; thus, data on the direct impact of body weight reduction on disease activity in SLE are limited.

The influence of body weight reduction on SLE activity has been addressed by Davies et al. (36). They enrolled 23 overweight female subjects (BMI: $>25 \mathrm{~kg} / \mathrm{m}^{2}$ ) with SLE who were on corticosteroid therapy. A 6-week controlled trial where a low glycaemic index diet $(n=11)$ or a calorie-restricted diet $(n=12)$ was implemented resulted in significant weight loss, reduction in waist and hip measurements and fatigue in both treatment groups. Of note, caloric restriction did not cause any flares of disease. However, these results must be interpreted with caution because they from only one study that addresses this issue, and the population studied was small. Nevertheless, it is surprising that such an important problem has not yet attracted greater attention, and more studies in this field are required. Presently, evidence supports the idea that a hypocaloric diet reduces the disease activity of SLE. By contrast, however, not all obese patients share inflammatory profiles, and not all individuals in a healthy weight range are metabolically healthy $(37,38)$. This underscores the need for proper nutrition or weight loss as only two factors of many for lupus patients (18). Lifestyle modifications such as meditation and exercise can also ameliorate lupus symptoms (39-43). Therefore, patients with SLE should maintain a balanced diet with caution to avoid excess daily calorie intake besides avoiding a sedentary lifestyle, especially in the case of obese patients or patients with a tendency toward obesity.

\section{Proteins}

The restriction of dietary protein has been addressed in several studies in patients with SLE and animal models. These data should be interpreted in a wider context as diet composition rather than protein restriction alone may show beneficial effects on SLE course. As an example, a traditional Mediterranean diet provides protection from certain chronic diseases including autoimmune disorders. This diet consists of vegetables, fruits, nuts, grains, olive oils and fish with limited meat consumption. Reduction of protein intake may be a reasonable approach in cases of lupus nephropathy as high protein intake contributes to reduced renal filtration, directly leading to the progression of kidney damage (44). Indeed, Milovanov et al. (45) observed that early restriction of dietary protein $(0.6 \mathrm{~g} / \mathrm{kg} /$ day $)$ slowed the decline in glomerular filtration rate in patients with SLE-induced chronic kidney disease. In a cross-sectional study on Brazilian juvenile subjects with $\operatorname{SLE}(n=22)$, consistent bone mineral loss was detected when subjects were treated with excessive proteins (46).

It has also been postulated that not only proteins but also selected amino acids may influence the course of SLE. In a case-controlled study, levels of serum L-canavanine (a nonproteinogenic amino acid) was significantly high $(p<0.01)$ in a group of Mexican patients with SLE $(n=100)$ compared with those of healthy controls $(n=100)$. This was therefore postulated to be a risk factor in developing SLE (47).

Among the many mechanisms by which amino acids modulate the immune response, regulation of mechanistic target of rapamycin (mTOR) attracts special attention. The signaling of mTOR is recognized as the most important intracellular pathway that coordinates local nutrients and systemic energy status at the organismal and cellular levels (48). Moreover, it is deeply involved in the immune response; thus, any dysfunction in this pathway may result in an aberrant immune response and predisposition to the development of autoimmunity (49). The role of the mTOR pathway is usually discussed in the context of T-cell function (50). It has been shown recently that T-cell dysfunction observed in SLE is at least partially due to the activation of mTOR caused by reduced glutathione (GSH) depletion via mitochondrial hyperpolarisation $(51,52)$. It was established that supplementation with $\mathrm{N}$-acetylcysteine (NAC), a precursor of GSH, significantly improved the activity of SLE disease by profoundly blocking mTOR activity $(p<0.0009)$ in $\mathrm{T}$ cells and reversing GSH depletion (53). Regarding the other amino acids, in case-controlled studies $(54,55)$, lower levels of tryptophan and higher levels of kynurenine (a metabolite of tryptophan) with activation of the kynurenine pathway were detected in patients with SLE. Indeed, an interventional study showed that NAC treatment significantly reduced the levels of kynurenine $\left(p=2.8 \times 10^{-7}\right)$ in patients with SLE (56). Therefore, supplementation with NAC or a GSH-rich diet and nutrients may exert a therapeutic role in the management of SLE.

Contrary to this, a diet low in phenylalanine and tyrosine showed a protective role against nephropathy (57) and reduced autoantibody production in a mouse model (NZB/W) of SLE (58). In another study, high L-arginine intake was associated with renal fibrosis and shortened the life span of MRL/lpr SLE mice (59).

Considering the role of proteins and amino acids, it should be emphasized that a diet of moderate protein intake is recommended, and a high-protein diet should be avoided especially by patients with lupus-related kidney diseases (e.g., overt lupus nephropathy). Major sources of dietary proteins are shown in Table $\mathbf{1}$ based on the United States Department of Agriculture (USDA) National Nutrient Database for Standard Reference (60).

\section{Essential Fatty Acids}

Fatty acids (FAs), especially polyunsaturated FAs (PUFAs), are an effective and essential dietary factor for patients with SLE (61). Among PUFAs, omega-3 ( $\omega-3)$ fatty acids [i.e., docosahexaenoic acid (DHA) and eicosapentaenoic acid (EPA)] can reduce the level of inflammatory mediators (Figure 2) as well as CRP. EPA and DHA can further reduce lymphocyte proliferation, macrophage-mediated and cytotoxic T-cell-mediated cytotoxicity, synthesis of proinflammatory cytokines, and chemotaxis from monocytes and neutrophils.

In a lupus-prone mouse model, when animals were fed with DHA, IFN-related genes were suppressed besides reduced autoantibody levels and glomerulonephritis (62). In another lupus-prone mouse model (female NZBWF1), the 
TABLE 1 | Major nutrient sources related to systemic lupus erythematosus.

\begin{tabular}{|c|c|c|}
\hline Nutrients & & Sources* \\
\hline \multicolumn{3}{|l|}{ MACRONUTRIENTS } \\
\hline Amino acids & & Eggs, meat, dairy products, pulses/legumes, whole cereals, royal jelly, and seafoods. \\
\hline \multirow[t]{2}{*}{ Polyunsaturated fatty acids } & Omega-3 & $\begin{array}{l}\text { Fish oil, krill oil, flaxseed oil, canola oil, soybean oil, olive oil, nuts, margarine, and fishes (i.e., salmon, tuna, sardine, } \\
\text { herring, mackerel, sablefish, whitefish). }\end{array}$ \\
\hline & Omega-6 & $\begin{array}{l}\text { Safflower oil, sunflower oil, soybean oil, maize oil, sesame oil, canola oil, corn oil, poppyseed oil, nuts, walnut oil, } \\
\text { primrose oil, margarine, ruminant, meat, eggs, and milk. }\end{array}$ \\
\hline Fiber & & $\begin{array}{l}\text { Beans, cereals, pulses/legumes, whole grains, vegetables, fruits, curry powder, cinnamon, dried rosemary, dried } \\
\text { oregano, coriander seed, dried basil, chili powder, and cloves. }\end{array}$ \\
\hline \multicolumn{3}{|l|}{ MICRONUTRIENTS } \\
\hline \multirow[t]{5}{*}{ Vitamins } & A & Carrots, sweet potatoes, pumpkins, spinach, shallots, kale, pepper, liver, fish oil, various meats, and tropical fruits. \\
\hline & B complex & $\begin{array}{l}\text { Fortified cereals, peanut butter, potatoes, dried peppers, nuts, banana, avocado, eggs, chicken, various red } \\
\text { meats, liver, mollusks, salmon, and sardine. }\end{array}$ \\
\hline & C & $\begin{array}{l}\text { Tangerine, orange juice, apple, papaya, guava, litchis, kiwi, broccoli, tomato, carrot, pepper, and whole cereals, } \\
\text { green tea, coriander leaf. }\end{array}$ \\
\hline & D & $\begin{array}{l}\text { Sunlight exposure, eggs, liver, fatty fishes (i.e., salmon eel, mackerel, trout sturgeon, swordfish, and sardine), fish } \\
\text { oil, cod liver, mushrooms, and supplemented dairy products. }\end{array}$ \\
\hline & E & $\begin{array}{l}\text { Wheat germ, sunflower oil and seeds, canola oil, soybean, whole cereals, nuts, almonds, peanut butter, milk, fish, } \\
\text { spinach, pepper, and margarine. }\end{array}$ \\
\hline \multirow[t]{6}{*}{ Minerals } & Calcium & Dairy products, dried basils, dried tofu, kale, soybean, spinach, sardine, and fortified whole cereals. \\
\hline & Zinc & Mollusks, whole cereals, peanut butter, seeds, white beans, soybean, spinach, milk, beef, turkey, and lamb. \\
\hline & Sodium & $\begin{array}{l}\text { Table salt, soy sauce, salted fishes (i.e., mackerel and salmon), wasabi, salted tofu, chili powder, canned foods, } \\
\text { and cheeses with salt. }\end{array}$ \\
\hline & Selenium & $\begin{array}{l}\text { Pike, carp, rainbow trout, mollusks, wheat germ, whole cereals, sunflower seeds, nuts, fish (tuna, cod, haddock, } \\
\text { salmon, crayfish, herring), egg, chicken liver, turkey, lamb, beef, mustard seed, fortified flours and products, and } \\
\text { ricotta. }\end{array}$ \\
\hline & Iron & $\begin{array}{l}\text { Fortified whole cereals, dried basil, dried spearmint, seaweed, cumin seed, fenugreek seed, turmeric, bay leaf, } \\
\text { soybeans, kale, pulses/legumes, mollusks, various meats, spinach, and broccoli. }\end{array}$ \\
\hline & Copper & $\begin{array}{l}\text { Beans, sesame seeds, sunflower seeds, dried basil, lentils, mushrooms, seaweed, nuts, mollusks, various meats, } \\
\text { and liver. }\end{array}$ \\
\hline Polyphenols & & $\begin{array}{l}\text { Various fruits and vegetables (i.e., grapes, oranges, watermelon, kiwi, apple, tomato, lettuce, broccoli, asparagus, } \\
\text { spinach, lentils, celery, parsley, thyme, and peppermint), green tea, coffee, walnut, green, and white beans, olive } \\
\text { oil, chamomile olives, and legumes. }\end{array}$ \\
\hline
\end{tabular}

*Based on the USDA, National Nutrient Database for Standard Reference 2018.

autoimmune response (i.e., increased levels of proinflammatory cytokines) was triggered by airway silica exposure, resulting in glomerulonephritis, lung damage and autoantibody formation. It was established that an isocaloric diet containing DHA reduced cytokine and chemokine synthesis, lymphocyte infiltration and autoantibody synthesis by plasma cells in this model (63).

In the mid-1980s, Kelley et al. in his pioneer study (64) demonstrated the direct impact of a fish oil diet (rich in EPA) on prostanoid metabolism and function that ultimately led to reduction of the inflammatory response in MRL/lpr mice. Many years later, the mechanism of this phenomenon was explained. The direct anti-inflammatory effect of EPA was due to the inhibition of cyclooxygenase (COX)-1, a key enzyme in the prostanoid synthesis pathway (65). Parallel to the inhibition of COX, fish oil $\omega-3$ PUFA suppressed autoantibody production and reduced the gene expression of inflammatory responserelated products, especially in the spleen and kidney of a murine SLE model. These mechanisms ultimately lead to the inhibition of glomerulonephritis and inflammation and prolong the lifespan of lupus-prone mice $(66,67)$. Fish oil maintained the enzymatic ratios of reduced GSH to oxidized GSH (GSH:GSSG) and the antioxidant profile in lupus-prone aged B/W mice (68). Furthermore, DHA-enriched fish oil reduced IgG deposition and caspase 1 in the kidney and anti-dsDNA antibody production and lipopolysaccharide-induced IL-18 production in the serum. It downregulated genes related to $\mathrm{CD} 4^{+} \mathrm{T}$ cells and decreased the expression of TNF- $\alpha, C D 80, C X C R 3, C T L A-4$, and various ILs (i.e., $I L-6, I L-10$, and $I L-18)$ in the kidneys and spleens of SLE-prone mice $(66,67)$.

Translationally, these immunomodulatory mechanisms assist to minimize inflammatory responses in patients with SLE (6971). Omega-3 PUFA from fish oil improved the endothelial function of patients with SLE in one study (72) but not in another (73). Besides their anti-inflammatory activity, dietary fish oil supplements also have played important roles in decreasing symptoms related to neuromotor and cardiovascular involvement and have improved conditions of fatigue and depression in patients with SLE $(72,74)$. Recently, in a double-blind randomized controlled trial, Seluang fish (Rasbora Spp.) oil (500 $\mu \mathrm{L} /$ day) reduced the inflammatory response in 
$\omega-3$ \& $\omega-6$ PUFA, fibre, vitamin $A$, vitamin $D$, vitamin

E, curcumin \& royal Jelly

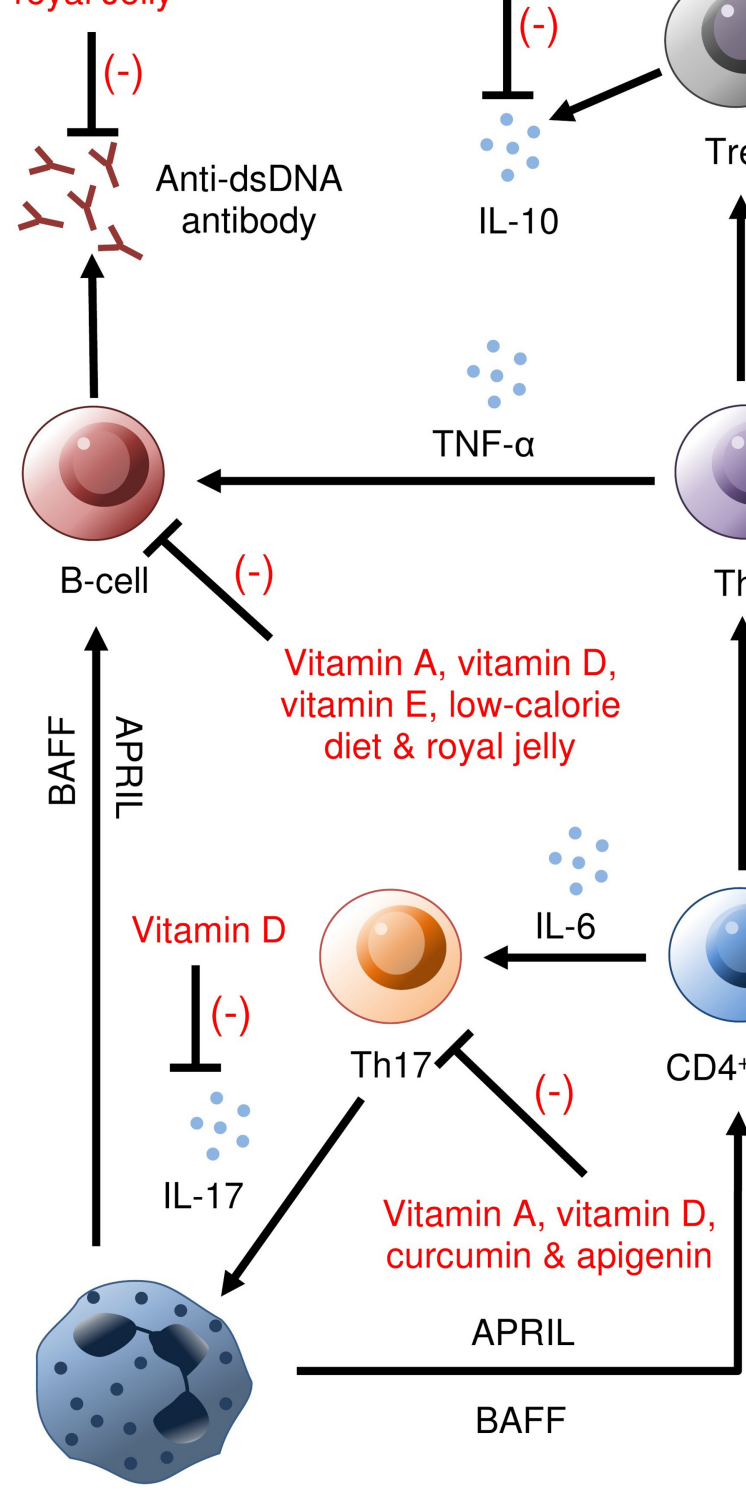

Vitamin A \& D, curcumin, EGCG \& royal jelly

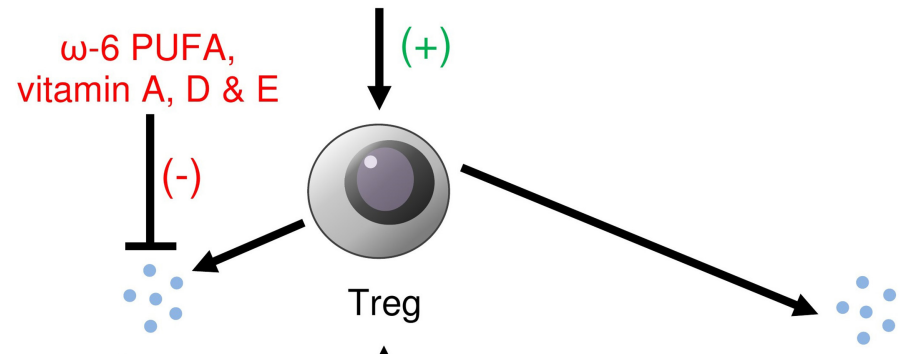

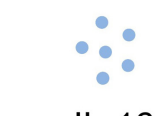

$\omega$-6 PUFA, TGF- $\beta$ $\therefore \quad$ vitamin $A, D$ \& E IL-2

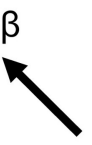

IL-1 $\beta$

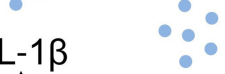

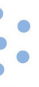
$-12$

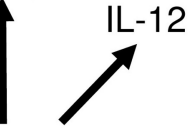

$(-)$

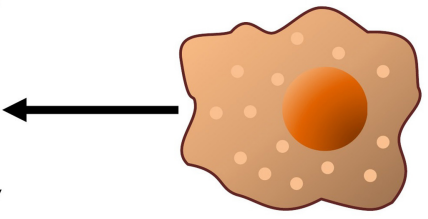

Activated Macrophage

Vitamin D \& apigenin

Neutrophil

FIGURE 2 | Immunomodulatory benefits of nutrients in SLE (based on the studies on human and animal models). In the immune-mediated pathogenesis of SLE, vitamin A inhibits anti-dsDNA antibodies, activation of B-cells, IFN- $\gamma$, CD4 $4^{+}$T-cell, Th17 cells, IL-10; vitamin D inhibits IL-10, IL-17, IFN- $\gamma, \mathrm{B}-\mathrm{cells}$, Th1, Th17, CD4+ T cells; $\omega$-3 PUFAs inhibit anti-dsDNA antibodies, CD4+ T-cells and $\omega-6$ PUFAs inhibit anti-dsDNA antibodies, IL-10, and IFN- $\gamma$. Vitamin A, vitamin D, curcumin, EGCG, and royal jelly were found to activate Treg cells. Anti-dsDNA, Anti-double-stranded DNA; PUFA, Polyunsaturated fatty acids; EGCG, Epigallocatechin-3-gallate.

patients with SLE by increasing serum levels of vitamin D and reducing IL-1, IL-6, and IL-17 (75). Altogether, concentrated fish oil increased the activity of renal antioxidant enzymes (i.e., GSH peroxidase and catalase) and serum vitamin D levels and reduced IL-1, IL-6, IL-1 $\beta$, IL-17, and TNF- $\alpha$ besides anti-dsDNA antibody production in the kidney, spleen and liver.

A similar conclusion comes from studies on linoleic acid ( $\omega$ 6 PUFA). Conjugated linoleic acid (CLA, an isomer of linoleic acid) demonstrated significant efficacy in SLE-induced rats by 
hindering cytokine and autoantibody production by controlling splenomegaly. It also obstructed oxidative stress as well as the nuclear factor kappa B (NF-kB) pathway and thus improved SLE activity and minimized mortality rates (76-78). Moreover, CLA demonstrated beneficial effects in SLE by improving the lipid profile in animal models by exhibiting antioxidant and anti-sclerotic activities (76-78).

Extra virgin olive oil (EVOO), as a main source of unsaturated fatty acids, reduced disease activity in a pristaneinduced SLE mouse model by influencing proinflammatory cytokine expression in the spleen and kidney besides regulating prostaglandin $\mathrm{E}_{2}$ levels in the kidney and matrix metalloproteinase- 3 in the serum. The potential mechanisms by which EVOO may exert beneficial effects on SLE activity may involve such pathways as mitogen-activated protein kinase, Janus kinase/signal transducer and activator of transcription, NF-кB, NF-E2-related factor-2, and heme oxygenase-1 pathways (79).

Only two studies addressed the role of fatty acids in patients with SLE. In a cross-sectional study on women with SLE $(n=$ 105), a diet with inflammatory potential (measured here as high dietary inflammatory index) was associated with a less-favorable lipid profile in patients with SLE (80). A population-based study $(n=456)$ suggested that a higher dietary intake of $\omega-3$ fatty acids and lower $\omega-6: \omega-3$ ratios were favorably associated with self-reported lupus activity and sleep quality (81). This is an interesting finding that suggests a direct influence of a $\omega$-3-rich diet on the disease activity and quality of life in patients with SLE. Among many mechanisms that may potentially explain this finding, the impact of EPA and DPA on the synthesis of serotonin has been recently proposed (82). Higher serotonin levels may simply alleviate dysfunction in the serotoninergic system, thereby contributing to the reduction of neuropsychiatric symptoms, depression and sleep disturbance (82).

Despite certain fatty acids significantly improving SLE conditions, some research has indicated ambiguity concerning their effectiveness in SLE (especially of $\omega-3$ and $\omega-6$ PUFAs), which are related to overconsumption, dose-dependent complexity, adverse immune responses and accelerated autoimmune symptoms; these should be carefully considered (83-85). Major sources of dietary PUFAs ( $\omega-3$ and $\omega-6)$, based on the United States Department of Agriculture (USDA), National Nutrient Database for Standard Reference (60), are shown in Table 1.

\section{Fiber}

Dietary fiber consists of edible carbohydrate polymers with three or more monomeric units that are resistant to endogenous digestive enzymes and are thus neither hydrolysed nor absorbed in the small intestine (86). Although fiber is present in a wide range of plant-based food sources, consumption is low in Western countries, contributing to changes in gut microbiota that may influence the development of serious gastrointestinal, cardiovascular and autoimmune disorders (87). Indeed, Statovci et al. (88) observed that a westernized diet with low fiber stimulates pathogenic bacterial growth inside the gut. Other studies also found a connection between fiber intake and diversity of intestinal microbiota $(89,90)$. Low levels of short-chain fatty acids (SCFAs), an end product of fiber fermentation, due to lower availability of dietary fiber can result in inflammation and imbalance in innate and adaptive immunity $(91,92)$. Parallel to this dietary residue, complex carbohydrates (fiber) are substrates for fermentation that produces SCFAs, and these serve as an energy source for gut microbiota. Thus, any changes in fiber intake may lead to a reduction of the population of gut microbiota (dysbiosis). Dysbiosis is not an uncommon phenomenon in patients with SLE and can be partially explained by the insufficient intake of dietary fiber (93-97). In a prospective study on Japanese female patients with SLE $(n=43)$ (98), an inverse correlation was observed between high intake of dietary fiber and risk of active, possibly through improving overall immune functions and suppressing active inflammation.

Therefore, an adequate intake of dietary fiber is recommended in patients with SLE because of the beneficial effects of fiber in reducing the disease activity by decreasing serum levels of autoantibodies and inflammatory cytokines. The major sources of dietary fiber are shown in Table $\mathbf{1}$ based on the United States Department of Agriculture (USDA), National Nutrient Database for Standard Reference (60).

\section{MICRONUTRIENTS}

Micronutrients comprise chemical compounds and essential elements that are required by organisms in varying quantities (usually very low) throughout life to orchestrate a range of metabolic activities to maintain health. This term usually refers to the vitamins and minerals that cannot be synthesized by the body and must be derived from the diet (99). Micronutrients typically can be divided into four categories: water-soluble vitamins, fatsoluble vitamins, microminerals and trace minerals.

\section{Vitamin A}

Vitamin A, a member of the fat-soluble vitamins, is an essential factor with multiple functions, including maintaining immune system, integrity and proper function besides acting upon nuclear retinoic acid receptors regulating transcription of several genes. In the MRL/lpr mouse model of lupus, vitamin A exerts paradoxical effects on the development of autoimmune lupus, resulting in decreasing inflammation in some organs or exacerbation of disease course in others (100). In another study with the (MRL/MPJ-lpr/lpr) SLE mouse model, vitamin A deficiency exerted a suppressive effect on the activities of abnormal $\mathrm{T}$ and $\mathrm{B}$ cells and suppressed serum anti-dsDNA antibody production (Figure 2) (101). Ikeda et al. (102) observed that $5-10 \mathrm{mg} / \mathrm{kg}$ oral administration of etretinate (a synthetic vitamin A derivative) significantly reduced dermal thickness ( $p$ $<0.05)$ in this SLE mouse model (MRL/lpr) compared with that of the controls by inducting apoptosis in dermal infiltrating cells and regulating cytokine production.

Considering human studies, Kinoshitak et al. (103) observed that after treatment with retinoids, levels of anti-dsDNA antibody and proteinuria were improved without side effects in patients with lupus nephritis. Daily intake of $100,000 \mathrm{U}$ of vitamin A produced enhanced antibody-dependent cellular cytotoxicity, natural killer cell and IL-2 activities in patients with SLE (104). 
In a case-controlled study with Indonesian patients with SLE ( $n$ $=62$ ), vitamin A modulated T-helper type (Th17), and Treg cell balance (105).

\section{Vitamin B}

The role of the vitamin B group in autoimmune patients is usually discussed in the context of its insufficiency. Indeed, several studies have indicated a low level of vitamin B in SLE patients in comparison with those of healthy controls. Vitamin $\mathrm{B}_{2}$ (riboflavin) deficiency was detected in $88 \%$ of a cohort of Chinese patients with SLE $(n=258)$ in an observational study (106). Similarly, significantly low levels of vitamin $\mathrm{B}_{12}$ (cobalamin) were observed $(<180 \mathrm{pg} / \mathrm{mL})$ in another cohort of patients with SLE $(n=43)$ when compared with those of healthy individuals $(p<0.0005)$; however, this was not significantly associated with disease activity (107). Later, in a prospective study on female Japanese patients with SLE $(n=43)(98)$, an inverse correlation was observed between a high intake of vitamin $\mathrm{B}_{6}$ (pyridoxine) (1.7 mg/day) and the risk of active SLE, possibly through improving overall immune functions and suppressing active inflammation. Furthermore, immunotherapy with vitamin $\mathrm{B}_{9}$ (folate) alleviated SLE-related symptoms in two lupus-prone mouse models (NXBW/F1 and MRL/MpJTnfrsf $6^{\text {pr }}$ ), leading to a significant prolongation of survival $(p=0.005)$ in both cases (25-53 vs. 16-31 weeks for untreated mice) (108).

\section{Vitamin C}

In a 4 year prospective study on Japanese patients with SLE $(n=279)$, it was observed that vitamin $C$ intake (109.99 $\mathrm{mg} /$ day) was significantly inversely associated $(p=$ 0.005) with the risk of developing active SLE (109). These researchers postulated that the antioxidant properties of vitamin $\mathrm{C}$ modulated immune functions, regulated the release of inflammatory mediators, decreased oxidative stress and suppressed autoantibody production in the SLE subjects. In a double-blind randomized placebo-controlled study of patients with SLE $(n=39)$, after a 12 week combined therapy with vitamin C (500 mg/day) and vitamin E (800 IU/day), reduction in lipid peroxidation was observed without affecting other oxidative stress markers or endothelial function (110).

\section{Vitamin D}

Recently, the role of vitamin D in the development of various autoimmune diseases has attracted attention. Vitamin D is commonly recognized as a pleiotropic compound, and its role goes beyond managing calcium metabolism. Not long ago, it was confirmed that vitamin D exerted a strong effect on cellular proliferation, differentiation and immune modulation. Congruently, vitamin D exerted protective effects in several diseases like hypertension, diabetes, cardiovascular diseases (CVDs), autoimmune diseases and cancer development (111). Studies on the role of vitamin D are especially important because vitamin D deficiency is commonly observed in people from developed countries and may potentially contribute to the increasing burden of autoimmune diseases in the last few years $(112,113)$.
A significantly high prevalence of vitamin D deficiency has been observed in patients with SLE in Saudi Arabia (114), Bahrain (115), the USA (116, 117), Canada (118), Jamaica (119), Brazil (120), France (121), Hungary (122), Denmark (123), and Spain $(124,125)$. In clinical studies on patients with SLE, significant inverse correlations were observed between serum levels of vitamin D and SLE disease activity index (SLEDAI) score in Malaysian (126), Taiwanese (127), Thai (128), Indian (129), Egyptian (130, 131), Saudi Arabian (132), Brazilian (133, 134), Australian (135), American (136), Hungarian (122), and Chinese (137) populations with an exception of Serbian SLE subjects $(n=$ 46) (138). Interestingly, two prolonged follow-up studies (up to 329 months) observed no associations between reported dietary intake of vitamin $\mathrm{D}$ during adolescence and risk of developing SLE in adulthood (139) and in adult women (140), suggesting that vitamin $\mathrm{D}$ metabolism may be at least partially related to inflammatory status in autoimmune patients. Several reasons for vitamin $\mathrm{D}$ inadequacy are independent of vitamin $\mathrm{D}$ dietary intake. Specifically, in lupus patients, vitamin D deficiency may be due to the avoidance of sunshine, photoprotection, impaired vitamin D synthesis (renal insufficiency) or the use of medications such as glucocorticoids, anticonvulsants, antimalarials, and calcineurin inhibitors, which exert a negative impact on the metabolism of vitamin D or downregulate the functions of the vitamin D receptor (113).

\section{Vitamin D and SLE Activity}

Considering the role of vitamin D deficiency on the development of SLE, Yu et al. (141) recently demonstrated that vitamin D plays a protective role in the autoantibody-induced injury of podocytes (kidney cells that wrap around capillaries of the glomerulus) in patients with lupus nephritis, which could be a potential novel therapeutic target to treat lupus nephritis. From a 24 week double-blind randomized placebo-controlled trial by Lima et al. (142), it was established that supplementation of vitamin $D$ in patients with juvenile-onset SLE effectively improved parameters of bone microarchitecture $(p=0.024)$. Bone marrow mesenchymal stem cells from patients with SLE show impaired proliferative capacity compared with that of normal controls (143). Administration of an analog of vitamin D (EB1089) promoted proliferation and osteogenic differentiation of stem cells by the Smad 1/5/8 signaling pathway (144). Although vitamin $\mathrm{D}$ deficiency was insignificantly correlated with higher SLEDAI scores in Egyptian patients with juvenile-onset SLE (145), it was later suggested that vitamin D supplementation was effective for a significant reduction of SLEDAI $(p=0.01)$ and improving fatigue $(p=0.008)$ in Brazilian patients with juvenileonset SLE (146). It was observed from two recent meta-analyses that the serum levels of vitamin D were significantly low $(p<$ 0.00001) in patients with SLE compared with those of healthy controls (147), and vitamin D supplementation was significantly effective $(p<0.001)$ in increasing these low serum vitamin D levels in patients with SLE with improved fatigue (148). In a group of patients with SLE, levels of $m T O R$ mRNA were higher in a group with severe vitamin $\mathrm{D}$ deficiency compared with a group with vitamin $\mathrm{D}$ insufficiency $(p=0.036)$ indicating that 
severe vitamin D deficiency contributes to SLE pathogenesis via increased expression of mTOR (149).

\section{Cytokines and Innate Immunity}

Increased levels of antinuclear antibodies, IL-23, and IL17 (important for Th17 development and function) were also significantly associated $(p<0.05)$ with a vitamin D deficiency (120). Abnormal activation of toll-like receptors (TLRs) contributes to the pathogenesis of SLE, and, interestingly, vitamin $\mathrm{D}$ exerts some of its immunomodulatory effects in patients with SLE by significantly downregulating the expression levels of TLR3 $(p=0.03)$, TLR7 $(p=0.0001)$, and TLR9 $(p=0.007)$ (150). Autoimmune diseases like SLE may result from a conversion of Treg cells into Th17 cells, and in the serum of patients with SLE, IL-17 levels were abnormally high. After 6 months of vitamin D supplementation in a group of Portuguese patients with SLE $(n=24)$, the FoxP3 ${ }^{+}$:IL-17A ratio was higher than that in the baseline $(p<0.001)$ (151). Similar conclusions arose from studies on IFNs. Low levels of vitamin $\mathrm{D}$ were significantly associated with high expression of IFN- $\alpha(p<0.05)$ (130) and high levels of IFN- $\alpha(p=0.02)$ (152) and IFN- $\gamma(p=0.03)$ (153) in the SLE group compared with the control group. Vitamin D deficiency was associated with impaired endothelial repair mechanisms and induction of CVDs with the potential to activate the type I IFN signaling pathway in SLE (154). Reynolds et al. (155) demonstrated that vitamin $\mathrm{D}$ positively modifies endothelial repair mechanisms by reducing $C X C L-10$ expression and thus reduces risks of CVDs in SLE. Handono et al. (156) showed that vitamin D significantly prevented endothelial damage $(p<0.05)$ induced by increased neutrophil extracellular trap formation in patients with SLE.

\section{Adaptive Immunity}

Vitamin D also induced the expansion of SLE Treg cells $\left(\mathrm{CD} 25^{\text {high }}\right.$ Foxp $\left.3^{+}\right)$. However, Schneider et al. (157) did not find any significant association between levels of vitamin D and cytokine profiles in SLE patients. After long-term (12 months) monthly treatment with vitamin $\mathrm{D}$ in patients with SLE, a significant enhancement $(p=0.03)$ of Treg cells $\left(\mathrm{CD}^{+}{ }^{+} \mathrm{CD} 45 \mathrm{RA}^{+} \mathrm{CCR}^{-}\right)$was observed (158). Similarly, lower levels of vitamin $\mathrm{D}$ caused a significant reduction $(p=0.015)$ in the percentage of migrated Treg cells $\left(\mathrm{CD} 4{ }^{+} \mathrm{CD} 25^{+} \mathrm{CCR} 4^{+}\right)$ compared with that of healthy controls (159). The CD4 ${ }^{+} / \mathrm{CD} 8^{+}$ ratio was significantly higher $(p<0.001)$ in patients with severe vitamin $\mathrm{D}$ deficiency compared with a vitamin Dinsufficient group (149), and vitamin D supplementation elevated $\mathrm{CD}^{+}{ }^{+} \mathrm{CD} 8^{+}$double-positive $\mathrm{T}$ cells $(160)$ or inhibited the activation of $\mathrm{CD}^{+}{ }^{+} \mathrm{T}$ cells (Figure 2 ) through inhibition of the PKC /ERK pathway and reduced expression of inflammatory factors (161). Through vitamin D supplementation for 6 months in patients with SLE $(n=20)$, hypovitaminosis D, Tregcell balance (increased Treg cells and decreased effector Th1 and Th17 cells) and B-cell homeostasis were restored with reduced anti-dsDNA antibodies (162). Low levels of vitamin $\mathrm{D}(<20 \mathrm{ng} / \mathrm{mL})$ were associated with reduced micro (mi)-RNA expression in T cells (i.e., miRNA-377, miRNA-342, miRNA-10a, miRNA-374b, miRNA-125a, and miRNA-410) of patients with SLE compared with those of healthy controls, indicating that unfavorable immunological alterations take place because of a lack of vitamin D in patients with SLE (163).

\section{Vitamin E}

Considering the pivotal role of vitamin $\mathrm{D}$ in the development of SLE, data on the fat-soluble vitamin E are still scanty. Some animal studies have addressed this problem with contradictory results. In the one study using SLE-prone NZB/W F1 mice as a model, high-dose vitamin $\mathrm{E}$ supplementation (550 $\mathrm{mg} / \mathrm{kg}$ all-rac- $\alpha$-tocopheryl acetate) decreased anti-dsDNA IgG antibody (Figure 2), oxidative stress, regulated cytokines (IFN$\gamma$ and IL- 6 secretion) and production of lymphocytes (B-cell differentiation), subsequently alleviating the severity of SLE with a prolonged lifespan (164). By contrast, Hsieh et al. (165) observed that low-dose vitamin E supplementation $(250 \mathrm{mg} / \mathrm{kg}$ all-rac- $\alpha$-tocopheryl acetate) was more beneficial for the survival of SLE-prone MRL/lpr mice, lowering the levels of anti-dsDNA, and anticardiolipin antibodies when compared with those of the high-dose group (500 mg/kg all-rac- $\alpha$-tocopheryl acetate).

Our current understanding of the role of vitamin $\mathrm{E}$ in the development of SLE in humans is also limited. From a prospective case-control study, lower levels of serum vitamin E were detected in a group of SLE patients $(0.64 \pm 0.09$ $\mathrm{mg} / \mathrm{dL})$ compared with those of normal controls $(0.80 \pm 0.21$ $\mathrm{mg} / \mathrm{dL}$ ) (166). According to the study of Maeshima et al. (167), oral administration of vitamin E (150-300 mg/day) in patients with SLE suppressed synthesis of antibodies via a mechanism independent of antioxidant activity. In a study with Egyptian patients with SLE $(n=25)(168)$, when Nigella sativa and vitamin $\mathrm{E}$ were supplemented together for 3 months, levels of antioxidant enzymes such as reduced GSH and superoxide dismutase were increased significantly when compared with the levels before supplementation $(p<0.001)$. Moreover, levels of IL-10, malondialdehyde, nitric oxide and inducible nitric oxide synthase decreased significantly compared with presupplementation levels $(p<0.001)$. Additionally, there was a significant decrease in antinuclear antibodies $(p<0.001)$, antidsDNA levels $(p<0.001)$, and SLEDAI score $(p<0.01)$.

\section{Minerals}

Like other micronutrients, minerals such as calcium, zinc, sodium, selenium, iron and copper generally attenuate SLE activity via different immunomodulatory mechanisms (Table 2). However, special attention must be given to mineral intake because it is best to restrict the consumption of some minerals like sodium. Table 2 shows the major dietary mineral sources based on the United States Department of Agriculture (USDA), National Nutrient Database for Standard Reference (60).

\section{NUTRACEUTICS}

Evidence accumulated over the past decade has demonstrated that various nutrients possess additional effects on body function 
TABLE 2 | Effects of dietary minerals on disease activities of SLE.

\begin{tabular}{|c|c|c|c|c|}
\hline Minerals & Study model & Country & Findings & Year, References \\
\hline \multirow[t]{4}{*}{ Calcium } & Cross-sectional & Spain & $\begin{array}{l}\text { Vitamin D-calcium supplementation increased the serum levels of vitamin } D \text {, however, do } \\
\text { not modify the serum calcium levels rather increased arterial stiffness significantly (IMT; } p \\
=0.041 \text { ). }\end{array}$ & 2019, (169) \\
\hline & $\begin{array}{l}\text { Prospective } \\
\text { interventional }\end{array}$ & Saudi Arabia & $\begin{array}{l}\text { Vitamin D-calcium supplementation significantly improved the bone mineral density in } \\
\text { vitamin D-deficient SLE patients, however, not significantly attenuated immune markers or } \\
\text { disease activity. }\end{array}$ & 2018, (170) \\
\hline & Case-control & Egypt & $\begin{array}{l}\text { There was no significant correlation between SLEDAI score and calcium supplementation } \\
(p=0.861) \text {. }\end{array}$ & 2016, (171) \\
\hline & Animal model & USA & $\begin{array}{l}\text { In presence of high-calcium diet, vitamin D supplement markedly suppress inflammatory } \\
\text { T-cell activity in experimental MRL/lpr SLE mice. }\end{array}$ & 2001, (172) \\
\hline \multirow[t]{3}{*}{ Zinc } & Animal model & USA & $\begin{array}{l}\text { Zinc restriction reduced autoantibodies (i.e., anti-dsDNA antibody) and lymphoproliferation } \\
\text { in MRL/lpr SLE mice. }\end{array}$ & 2001, (173) \\
\hline & Animal model & USA & $\begin{array}{l}\text { Zinc-deficient diet retarded autoantibody (i.e., anti-dsDNA antibody) production in } \\
\text { NZB/NZW SLE mice. }\end{array}$ & 1982, (174) \\
\hline & Animal model & USA & Depot-zinc therapy significantly reduced kidney damage in the BN SLE mice $(p<0.01)$. & 1981, (175) \\
\hline \multirow[t]{3}{*}{ Sodium } & Cross-sectional & Mexico & $\begin{array}{l}\text { A positive correlation was detected between sodium intake and levels of } \\
\text { CD4 }{ }^{+} \text {CD } 25^{+} \text {Foxp3 } 3^{+} \text {Treg cells in SLE. }\end{array}$ & 2018, (176) \\
\hline & Prospective & Italy & $\begin{array}{l}\text { Due to dietary sodium intake, Th17 and Treg cells significantly decreased }(p=0.01) \text { and } \\
\text { increased }(p=0.04) \text {, respectively. Additionally, serum IL-9 levels were significantly } \\
\text { reduced in SLE patients }(p=0.03) \text {. }\end{array}$ & $2017,(177)$ \\
\hline & Animal model & China & $\begin{array}{l}\text { Excessive intake of sodium in diet aggravated lupus nephritis through SGK1 pathway by } \\
\text { significantly increasing the Th1/Th2 and Th17/Treg ratios in MRL/Ipr SLE mice. }\end{array}$ & 2015, (178) \\
\hline \multirow[t]{2}{*}{ Selenium } & Animal model & USA & $\begin{array}{l}\text { Selenium supplementation leads to impaired differentiation and maturation of } \\
\text { macrophages. }\end{array}$ & (179) \\
\hline & & & $\begin{array}{l}\text { Selenium in the drinking water significantly improved the survival rate }(p<0.04) \text { and } \\
\text { increased NK cell activity }(p<0.001) \text { of the NZB/NZW SLE mice though there was no } \\
\text { effect on autoantibody (i.e., anti-SsDNA antibody) production. }\end{array}$ & 1988, (180) \\
\hline Iron & Animal model & USA & $\begin{array}{l}\text { Anemia and incidence of skin lesions were high in severely iron deficient MRL/MPJ-/pr/lpr } \\
\text { SLE mice. }\end{array}$ & 1995, (181) \\
\hline Copper & $\begin{array}{l}\text { Double blind, double } \\
\text { placebo-controlled trial }\end{array}$ & Ireland & No significant effect on SLAM-R was observed. & 2004, (182) \\
\hline
\end{tabular}

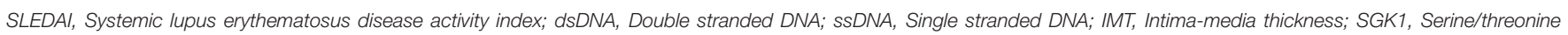
protein kinase 1; Th, Thelper; Treg, Regulatory T; IL, Interleukin; NK, Natural killer; SLAM-R, Revised Systemic Lupus Activity Measure.

and metabolism. Concordantly, several studies have shown that nutrients modify the immune response as well as the integrity of the organs and tissues. In connective tissue diseases where a pharmacological approach is limited and introduces the risk of several severe side effects, there is a demand for compounds that potentially exert beneficial effects without side effects. Such compounds are commonly referred to as nutraceuticals, and this approach, although a bit controversial, has been tested in several SLE studies.

\section{Polyphenols Curcumin}

Curcumin, a major natural polyphenol of turmeric, exerted a protective effect against lupus nephritis in SLE-prone MRL/lpr mice by reducing serum anti-dsDNA antibody levels and inhibiting the expression of the NLRP3 inflammasome, which is believed to be a key player in the development of lupus nephritis (183). An experimental study with SLE-prone MRL/lpr mice demonstrated that curcumin aggravated CNS pathology (184). Moreover, curcumin decreased anti-dsDNA IgG antibodies and attenuated lupus nephritis upon interaction with Treg cells in SLE-prone NZB/W F1 female mice (185).

Direct translation of these promising data into clinical application is a difficult task; data in this field are scarce and frequently controversial. In a small double-blind randomized controlled trial $(n=39)$, when curcumin was administered along with vitamin D in a group of patients with SLE who displayed hypovitamin $\mathrm{D}$, no significant differences arose in SLEDAI reduction or decreased serum IL-6 and increased TGF- $\beta 1$ (186). Contrary to this, another study revealed that administration of low doses of curcumin $(0.1$ and $1.0 \mu \mathrm{g} / \mathrm{mL})$ to cultured $\mathrm{CD}^{+}$cells from patients with SLE significantly $(p<0.001)$ modulated the Th17/Treg balance without affecting healthy subjects (187). Similar to this in vitro experiment, low-dose curcumin $(0.1 \mu \mathrm{g} / \mathrm{mL})$ inhibited the expression and activation of PYK2 in peripheral blood mononuclear cells (PBMCs) and reduced the proliferation of PBMCs in patients with lupus nephritis (188).

Although the results of completed studies are somewhat promising, they are inconclusive, and more studies on the role of curcumin in SLE are warranted. 


\section{Virgin Olive Oil}

In a pristane-induced $\mathrm{BALB} / \mathrm{c}$ mouse model of SLE, administration of virgin olive oil (VOO) and its phenol fraction (with major components of hydroxytyrosol, tyrosol, oleuropein aglycone, and ligstroside aglycone) counteracted inflammatory pathways in cells of the monocytemacrophage lineage (189). Therefore, both VOO and its phenol fraction are promising immunomodulators of SLE activity. Epigallocatechin-3-gallate (EGCG), the major bioactive polyphenol present in green tea, enhanced the Nrf2 antioxidant signaling pathway, decreased renal NLRP3 inflammasome activation and increased systemic Treg cell activity in NZB/W F1 SLE-prone mice (190). EGCG attenuated inflammation in mesangial cells of SLE-prone MRL/lpr mice via the PI3K/Akt/mTOR pathway by decreasing Akt phosphorylation (191).

Limited data exist on the role of VOO in modulating the immune response in SLE patients. An in vitro study on PBMCs derived from SLE patients (192) showed that the phenol fraction of VOO was successful in modulating cytokine production and attenuated induced T-cell activation, most likely through the NF- $\kappa$ B signaling pathway.

\section{Polyphenols and Microbiota}

Cuervo et al. (193) determined an association between polyphenol intake and fecal microbiota in Spanish patients with SLE compared with healthy controls. Major dietary sources of polyphenols include various fruits and vegetables (oranges, lettuce, watermelon, kiwi, tomato, apple, lentils and celery) as assessed through a semi-quantitative foodfrequency questionnaire. Interestingly, a well-balanced diet with a high intake of apples and oranges besides other fruits and vegetables rich in flavonoids has been associated with the presence of beneficial microorganisms (i.e., Lactobacillus, Blautia, and Bifidobacterium) in the fecal matter of these patients with SLE.

\section{Flavonoids}

The results of a 6 year survey collected in 2016 showed that higher serum levels of lycopene (enriched in tomatoes, red carrots and watermelons) have a significant protective effect on mortality when compared with lower levels (5.3 vs. $33.3 \%$; $p=0.04$ ) in subjects with SLE (194). Apigenin (a mutagenic flavonoid rich in parsley, thyme, peppermint, olives and chamomile) inhibited autoantigen presentation and stimulatory functions of antigen-presenting cells necessary for activation and expansion of autoreactive Th1 and Th17 cells (Figure 2) and B cells in SLE by downregulation of COX-2 expression (195). Nevertheless, Pocovi-Gerardino et al. (196) documented no significant correlation between the dietary intake of macronutrients, micronutrients or antioxidants, and serum levels of CRP in patients with SLE.

\section{Royal Jelly}

Royal jelly, a creamy product secreted by young nurse worker bees (Apis mellifera), is composed of $10-12 \%$ carbohydrates, $12-15 \%$ proteins, and $3-7 \%$ lipids, vitamins, minerals and polyphenols. In an open-label study, children with SLE ( $n$ $=20$ ) received $2 \mathrm{~g}$ of freshly prepared royal jelly daily for 12 weeks. The SLEDAI score significantly improved $(p=$ 0.01 ) after 3 months of royal jelly therapy. Complement C3 $(p=0.009)$ and C4 $(p=0.014)$ levels also significantly increased at the end of the 12 -week treatment. Additionally, percentages of $\mathrm{CD} 4^{+} \mathrm{CD} 25^{\text {thigh }}$ and $\mathrm{CD} 4^{+} \mathrm{CD} 25^{+ \text {high }} \mathrm{FOXP} 3^{+}$ cells $\left(\mathrm{CD}^{+}\right.$Treg cells) were significantly increased after royal jelly treatment $(p<0.01)$; however, the frequency of Treg cells remained significantly lower than that in the control group $(p=0.01)$. Moreover, $\mathrm{CD} 8^{+} \mathrm{CD} 25^{\text {thigh }}$ and $\mathrm{CD}^{+}{ }^{+} \mathrm{CD} 25^{+ \text {high }} \mathrm{FOXP}^{+}$cells $\left(\mathrm{CD} 8^{+}\right.$Treg cells) significantly increased after royal jelly treatment $(p<0.01)$. Percentages of $\mathrm{CD} 8^{+} \mathrm{CD} 25^{\text {thigh }}$ and $\mathrm{CD} 8^{+}$Treg cells in patients with SLE at baseline (prior to royal jelly treatment) were significantly lower than in the control group of children without SLE ( $p=$ 0.003) (197).

In another study, when royal jelly was administered in a group of SLE-prone NZB/NZW F1 female mice, a significant delay in the onset of the disease and prolonged lifespan were observed. Additionally, serum levels of anti-ssDNA, antidsDNA antibodies and autoreactive B cells were significantly decreased (198).

\section{CONCLUSIONS}

Because dietary supplementation of various macronutrients and micronutrients has exhibited immunomodulatory effects including maintenance of homeostasis and improvement of physical and mental well-being of patients with SLE, it is recommended that these patients consume a balanced diet that is low in calories and protein but contains plenty of fiber, PUFAs $(\omega-$ 3 and $\omega-6)$, vitamins (A, B, C, D, and E), minerals (calcium, zinc, selenium, iron and copper) and polyphenol-containing foods.

\section{AUTHOR CONTRIBUTIONS}

MI contributed to the conception of the work, developed the search strategy, conducted the literature search and drafted the manuscript. SK assisted in writing and drawing Figure 2. PK and $\mathrm{RH}$ substantively revised the manuscript. All the authors approved the final submitted version of the manuscript.

\section{SUPPLEMENTARY MATERIAL}

The Supplementary Material for this article can be found online at: https://www.frontiersin.org/articles/10.3389/fimmu. 2020.01477/full\#supplementary-material 


\section{REFERENCES}

1. Ali M, Firoz CK, Jabir NR, Rehan M, Khan MS, Tabrez S. An insight on the pathogenesis and treatment of systemic lupus erythematosus. Endocr Metab Immune Disord Drug Targets. (2018) 18:110-23. doi: 10.2174/1871530318666171207145003

2. Jeong DY, Lee SW, Park YH, Choi JH, Kwon YW, Moon G, et al. Genetic variation and systemic lupus erythematosus: a field synopsis and systematic meta-analysis. Autoimmun Rev. (2018) 17:553-66. doi: 10.1016/j.autrev.2017.12.011

3. Farivar S, Aghamaleki FS. Effects of major epigenetic factors on systemic lupus erythematosus. Iran Biomed J. (2018) 22:294-302. doi: 10.29252/ibj.22.5.294

4. Aringer M, Costenbader K, Daikh D, Brinks R, Mosca M, RamseyGoldman R, et al. European league against rheumatism/american college of rheumatology classification criteria for systemic lupus erythematosus. Arthritis Rheumatol. (2019) 71:1400-12. doi: 10.1002/art.40930

5. Maidhof W, Hilas O. Lupus: an overview of the disease and management options. Pharm Ther. (2012) 37:240-6.

6. Tsokos GC. Systemic lupus erythematosus. N Engl J Med. (2011) 365:211021. doi: 10.1056/NEJMra1100359

7. Stojan G, Petri M. Epidemiology of systemic lupus erythematosus: an update. Curr Opin Rheumatol. (2018) 30:144-50. doi: 10.1097/BOR.0000000000000480

8. Aparicio-Soto M, Sánchez-Hidalgo M, Alarcón-de-la-Lastra C. An update on diet and nutritional factors in systemic lupus erythematosus management. Nutr Res Rev. (2017) 30:118-37. doi: 10.1017/S0954422417000026

9. Katz-Agranov N, Zandman-Goddard G. The microbiome and systemic lupus erythematosus. Immunol Res. (2017) 65:4327. doi: 10.1007/s12026-017-8906-2

10. de Medeiros MCS, Medeiros JCA, de Medeiros HJ, Leitão JCGdC, Knackfuss MI. Dietary intervention and health in patients with systemic lupus erythematosus: a systematic review of the evidence. Crit Rev Food Sci Nutr. (2018) 59:2666-73. doi: 10.1080/10408398.2018.1463966

11. Perricone C, Agmon-Levin N, Colafrancesco S, Shoenfeld Y. Vitamins and systemic lupus erythematosus: to D or not to D. Expert Rev Clin Immunol. (2013) 9:397-9. doi: 10.1586/eci.13.23

12. Teng X, Brown J, Choi SC, Li W, Morel L. Metabolic determinants of lupus pathogenesis. Immunol Rev. (2020) 295:167-86. doi: 10.1111/imr.12847

13. Constantin MM, Nita IE, Olteanu R, Constantin T, Bucur S, Matei C, et al. Significance and impact of dietary factors on systemic lupus erythematosus pathogenesis. Exp Ther Med. (2019) 17:1085-90. doi: 10.3892/etm.2018.6986

14. dos Santos FdMM, Borges MC, Telles RW, Correia MIT, Lanna CCD. Excess weight and associated risk factors in patients with systemic lupus erythematosus. Rheumatol Int. (2013) 33:681-8. doi: 10.1007/s00296-012-2402-8

15. Elkan A, Anania C, Gustafsson T, Jogestrand T, Hafström I, Frostegård J. Diet and fatty acid pattern among patients with SLE: associations with disease activity, blood lipids and atherosclerosis. Lupus. (2012) 21:140511. doi: 10.1177/0961203312458471

16. Kotyla P. Insulin resistance varies across connective tissue diseases patients: comparison between rheumatoid arthritis, systemic lupus erythematosus and systemic sclerosis. Clin Exp Rheumatol. (2019) 37:14.

17. Liu Y, Kaplan MJ. Cardiovascular disease in systemic lupus erythematosus: an update. Curr Opin Rheumatol. (2018) 30:441-8. doi: 10.1097/BOR.0000000000000528

18. Borges MC, dos Santos FdMM, Telles RW, Lanna CCD, Correia MIT. Nutritional status and food intake in patients with systemic lupus erythematosus. Nutrition. (2012) 28:1098103. doi: 10.1016/j.nut.2012.01.015

19. Oeser A, Chung CP, Asanuma Y, Avalos I, Stein CM. Obesity is an independent contributor to functional capacity and inflammation in systemic lupus erythematosus. Arthritis Rheum. (2005) 52:36519. doi: 10.1002/art.21400

20. Cozier YC, Barbhaiya M, Castro-Webb N, Conte C, Tedeschi S, Leatherwood $\mathrm{C}$, et al. A prospective study of obesity and risk of systemic lupus erythematosus (SLE) among black women. Semin Arthritis Rheum. (2019) 48:1030-4. doi: 10.1016/j.semarthrit.2018.10.004
21. Teh P, Zakhary B, Sandhu VK. The impact of obesity on SLE disease activity: findings from the Southern California Lupus Registry (SCOLR). Clin Rheumatol. (2019) 38:597-600. doi: 10.1007/s10067-018-4336-3

22. Castrejon I, Shakoor N, Block J, Pincus T. Higher rates of obesity and associations with poorer clinical status in patients with RA, OA and SLE: a cross-sectional study from routine care. Ann Rheum Dis. (2017) 76:14512. doi: 10.1136/annrheumdis-2017-eular.3812

23. Sinicato NA, Postal M, Peres FA, Peliçari KdO, Marini R, dos Santos AdO, et al. Obesity and cytokines in childhood-onset systemic lupus erythematosus. J Immunol Res. (2014) 2014:1-10. doi: 10.1155/2014/162047

24. Patterson SL, Schmajuk G, Jafri K, Yazdany J, Katz P. Obesity is independently associated with worse patient-reported outcomes in women with systemic lupus erythematosus. Arthritis Care Res. (2019) 71:12633. doi: 10.1002/acr.23576

25. Sun D, Krishnan A, Su J, Lawrence R, Zaman K, Fernandes G. Regulation of immune function by calorie restriction and cyclophosphamide treatment in lupus-prone NZB/NZW F1 mice. Cell Immunol. (2004) 228:5465. doi: 10.1016/j.cellimm.2004.04.001

26. Feng Y, Yang M, Wu H, Lu Q. The pathological role of B cells in systemic lupus erythematosus: From basic research to clinical. Autoimmunity. (2020) 53:56-64. doi: 10.1080/08916934.2019.1700232

27. Yap DY, Chan TM. B cell abnormalities in systemic lupus erythematosus and lupus nephritis - role in pathogenesis and effect of immunosuppressive treatments. Int J Mol Sci. (2019) 20:6231. doi: 10.3390/ijms20246231

28. Urao M, Ueda G, Abe M, Kanno K, Hirose S, Shirai T. Food restriction inhibits an autoimmune disease resembling systemic lupus erythematosus in $(\mathrm{NZB} \times \mathrm{NZW})$ F1 mice. J Nutr. (1995) 125:231624. doi: $10.1093 /$ jn/125.9.2316

29. Troyer D, Chandrasekar B, Barnes J, Fernandes G. Calorie restriction decreases platelet-derived growth factor (PDGF)-A and thrombin receptor mRNA expression in autoimmune murine lupus nephritis. Clin Exp Immunol. (1997) 108:58-62. doi: 10.1046/j.1365-2249.1997.d01-970.x

30. Zhao X, Hao J, Duan H, Rong Z, Li F. Phosphoinositide 3-kinase/protein kinase $\mathrm{B} /$ periostin mediated platelet-derived growth factor-induced cell proliferation and extracellular matrix production in lupus nephritis. Exp Biol Med. (2017) 242:160-8. doi: 10.1177/1535370216668050

31. Muthukumar AR, Jolly CA, Zaman K, Fernandes G. Calorie restriction decreases proinflammatory cytokines and polymeric Ig receptor expression in the submandibular glands of autoimmune prone $(\mathrm{NZB} \times \mathrm{NZW}) \mathrm{F} 1$ mice. J Clin Immunol. (2000) 20:354-61. doi: 10.1023/a:1006620130114

32. Bristow C, Meurer C, Simmonds J, Snell T. Anti-obesity public health messages and risk factors for disordered eating: a systematic review. Health Promot Int. (2020). doi: 10.1093/heapro/daaa018. [Epub ahead of print].

33. Thomas PE, Jensen BW, Sørensen KK, Jacobsen S, Aarestrup J, Baker JL. Early life body size, growth and risks of systemic lupus erythematosusA large Danish observational cohort study. Semin Arthritis Rheum. [Epub ahead of print]. (2020). doi: 10.1016/j.semarthrit.2020.01.011

34. Meza-Meza MR, Vizmanos-Lamotte B, Muñoz-Valle JF, Parra-Rojas I, Garaulet M, Campos-López B, et al. Relationship of excess weight with clinical activity and dietary intake deficiencies in systemic lupus erythematosus patients. Nutrients. (2019) 11:2683. doi: 10.3390/nu11112683

35. Kang JH, Xu H, Choi SE, Park DJ, Lee JK, Kwok SK, et al. Obesity increases the incidence of new-onset lupus nephritis and organ damage during followup in patients with systemic lupus erythematosus. Lupus. (2020) 6:57886. doi: 10.1177/0961203320913616

36. Davies R, Lomer M, Yeo S, Avloniti K, Sangle S, D’Cruz D. Weight loss and improvements in fatigue in systemic lupus erythematosus: a controlled trial of a low glycaemic index diet versus a calorie restricted diet in patients treated with corticosteroids. Lupus. (2012) 21:64955. doi: $10.1177 / 0961203312436854$

37. Ding C, Chan Z, Magkos F. Lean, but not healthy: the 'metabolically obese, normal-weight'phenotype. Curr Opin Clin Nutr Metab Care. (2016) 19:40817. doi: 10.1097/MCO.0000000000000317

38. Lavie CJ, De Schutter A, Milani RV. Healthy obese versus unhealthy lean: the obesity paradox. Nat Rev Endocrinol. (2015) 11:55-62. doi: 10.1038/nrendo.2014.165

39. Ayán C, Martin V. Systemic lupus erythematosus and exercise. Lupus. (2007) 16:5-9. doi: 10.1177/0961203306074795 
40. Bantornwan S, Watanapa WB, Hussarin P, Chatsiricharoenkul S, Larpparisuth N, Teerapornlertratt $\mathrm{T}$, et al. Role of meditation in reducing sympathetic hyperactivity and improving quality of life in lupus nephritis patients with chronic kidney disease. J Med Assoc Thai. (2014) 97:101-7.

41. Clarke-Jenssen AC, Fredriksen PM, Lilleby V, Mengshoel AM. Effects of supervised aerobic exercise in patients with systemic lupus erythematosus: a pilot study. Arthritis Care Res. (2005) 53:308-12. doi: 10.1002/art.21082

42. Tench C, McCarthy J, McCurdie I, White P, D'Cruz D. Fatigue in systemic lupus erythematosus: a randomized controlled trial of exercise. Rheumatology. (2003) 42:1050-4. doi: 10.1093/rheumatology/ keg289

43. Benatti FB, Miyake CN, Dantas WS, Zambelli VO, Shinjo SK, Pereira RM, et al. Exercise increases insulin sensitivity and skeletal muscle AMPK expression in systemic lupus erythematosus: a randomized controlled trial. Front Immunol. (2018) 9:906. doi: 10.3389/fimmu.2018.00906

44. Milovanov I, Lysenko L, Milovanova L, Dobrosmyslov I. The role of balanced low-protein diet in inhibition of predialysis chronic kidney disease progression in patients with systemic diseases. Ter Arkh. (2009) 81:52-7.

45. Milovanov YS, Milovanova LY, Mikhailov A, Aleksandrova I. Influence of diet balanced with essential amino acids/keto acid analogs and high-nutrient blend on the progression of renal failure in patients in the pre-dialysis stage of chronic kidney disease caused by systemic autoimmune diseases. Int $J$ Biomed. (2013) 3:184-7.

46. Caetano MC, Ortiz TT, Terreri MTS, Sarni RO, Silva SG, Souza FI, et al. Inadequate dietary intake of children and adolescents with juvenile idiopathic arthritis and systemic lupus erythematosus. J Pediatr. (2009) 85:509-15. doi: 10.2223/JPED.1941

47. Ruíz-Bedolla E, López-Martínez B, Parra-Ortega I. Evaluation of the amino acid L-canavanine in the serum of patients with systemic lupus erythematosus. Rev Latinoamer Patol Clin. (2016) 63:87-90. doi: 10.1016/B978-0-12-801917-7.00009-7

48. Mao Z, Zhang W. Role of mTOR in glucose and lipid metabolism. Int J Mol Sci. (2018) 19:2043. doi: 10.3390/ijms19072043

49. Liu Y, Zhang DT, Liu XG. mTOR signaling in $\mathrm{T}$ cell immunity and autoimmunity. Int Rev Immunol. (2015) 34:5066. doi: 10.3109/08830185.2014.933957

50. Bi Y, Liu G, Yang R. mTOR regulates T-cell differentiation and activation in immunity and autoimmunity. Crit Rev Eukaryot Gene Expr. (2011) 21:31322. doi: 10.1615/CritRevEukarGeneExpr.v21.i4.20

51. Gergely P Jr, Grossman C, Niland B, Puskas F, Neupane H, Allam F, et al. Mitochondrial hyperpolarization and ATP depletion in patients with systemic lupus erythematosus. Arthritis Rheum. (2002) 46:175-90. doi: 10. 1002/1529-0131(200201)46:1<175::AID-ART10015>3.0.CO;2-H

52. Shah D, Aggarwal A, Bhatnagar A, Kiran R, Wanchu A. Association between T lymphocyte sub-sets apoptosis and peripheral blood mononuclear cells oxidative stress in systemic lupus erythematosus. Free Radic Res. (2011) 45:559-67. doi: 10.3109/10715762.2011.555765

53. Lai ZW, Hanczko R, Bonilla E, Caza TN, Clair B, Bartos A, et al. $\mathrm{N}$-acetylcysteine reduces disease activity by blocking mammalian target of rapamycin in $\mathrm{T}$ cells from systemic lupus erythematosus patients: a randomized, double-blind, placebo-controlled trial. Arthritis Rheum. (2012) 64:2937-46. doi: 10.1002/art.34502

54. Bengtsson AA, Trygg J, Wuttge DM, Sturfelt G, Theander E, Donten M, et al. Metabolic profiling of systemic lupus erythematosus and comparison with primary Sjögren's syndrome and systemic sclerosis. PLoS ONE. (2016) 11:e0159384. doi: 10.1371/journal.pone.0159384

55. Zhang Q, Yin X, Wang H, Wu X, Li X, Li Y, et al. Fecal metabolomics and potential biomarkers for systemic lupus erythematosus. Front Immunol. (2019) 10:1-10. doi: 10.3389/fimmu.2019.00976

56. Perl A, Hanczko R, Lai Z-W, Oaks Z, Kelly R, Borsuk R, et al. Comprehensive metabolome analyses reveal $\mathrm{N}$-acetylcysteine-responsive accumulation of kynurenine in systemic lupus erythematosus: implications for activation of the mechanistic target of rapamycin. Metabolomics. (2015) 11:115774. doi: 10.1007/s11306-015-0772-0

57. Dubois EL, Strain L. Effect of diet on survival and nephropathy of NZB-NZW hybrid mice. Biochem Med. (1973) 7:33640. doi: 10.1016/0006-2944(73)90091-4
58. Corman LC. The role of diet in animal models of systemic lupus erythematosus: possible implications for human lupus. Semin Arthritis Rheum. (1985) 15:61-9. doi: 10.1016/0049-0172(85)90010-1

59. Peters H, Border WA, Rückert $M$, Krämer S, Neumayer HH, Noble NA. L-arginine supplementation accelerates renal fibrosis and shortens life span in experimental lupus nephritis. Kidney Int. (2003) 63:138292. doi: 10.1046/j.1523-1755.2003.00881.x

60. US Department of Agriculture. Agricultural Research Service, Nutrient Data Laboratory. USDA, National Nutrient Database for Standard Reference. Legacy Release, Beltsville (2018).

61. Huerta MDR, Trujillo-Martin MM, Rua-Figueroa I, Cuellar-Pompa L, Quiros-Lopez R, Serrano-Aguilar P, et al. Healthy lifestyle habits for patients with systemic lupus erythematosus: a systemic review. Semin Arthritis Rheum. (2016) 45:463-70. doi: 10.1016/j.semarthrit.2015.09.003

62. Wierenga KA, Harkema JR, Pestka JJ. Lupus, silica, and dietary omega-3 fatty acid interventions. Toxicol Pathol. (2019) 47:1004-11. doi: 10.1177/0192623319878398

63. Bates MA, Brandenberger C, Langohr II, Kumagai K, Lock AL, Harkema JR, et al. Silica-triggered autoimmunity in lupus-prone mice blocked by docosahexaenoic acid consumption. PLOS ONE. (2016) 11:1-31. doi: 10.1371/journal.pone.0160622

64. Kelley V, Ferretti A, Izui S, Strom T. A fish oil diet rich in eicosapentaenoic acid reduces cyclooxygenase metabolites, and suppresses lupus in MRL-lpr mice. J Immunol. (1985) 134:1914-9.

65. Smith WL. Cyclooxygenases, peroxide tone and the allure of fish oil. Curr Opin Cell Biol. (2005) 17:174-82. doi: 10.1016/j.ceb.2005.02.005

66. Pestka JJ, Vines LL, Bates MA, He K, Langohr I. Comparative effects of n-3, n-6 and n-9 unsaturated fatty acid-rich diet consumption on lupus nephritis, autoantibody production and $\mathrm{CD} 4+\mathrm{T}$ cell-related gene responses in the autoimmune NZBWF1 mouse. PLoS ONE. (2014) 9:118. doi: 10.1371/journal.pone. 0100255

67. Halade GV, Rahman MM, Bhattacharya A, Barnes JL, Chandrasekar B, Fernandes G. Docosahexaenoic acid-enriched fish oil attenuates kidney disease and prolongs median and maximal life span of autoimmune lupusprone mice. J Immunol. (2010) 184:5280-6. doi: 10.4049/jimmunol.0903282

68. Kim YJ, Yokozawa T, Chung HY. Effects of energy restriction and fish oil supplementation on renal guanidino levels and antioxidant defences in aged lupus-prone B/W mice. Br J Nutr. (2005) 93:83544. doi: 10.1079/BJN20051440

69. Everett ST, Wolf R, Contento I, Haiduc V, Richey M, Erkan D. Shortterm patient-centered nutrition counseling impacts weight and nutrient intake in patients with systemic lupus erythematosus. Lupus. (2015) 24:13216. doi: $10.1177 / 0961203315582284$

70. Borges MC, Santos FdMM, Telles RW, Correia MITD, Lanna CCD. Polyunsaturated omega-3 fatty acids and systemic lupus erythematosus: what do we know? Rev Bras Reumatol. (2014) 54:459-66. doi: 10.1016/j.rbre.2013.12.002

71. Calder PC. The 2008 ESPEN sir david cuthbertson lecture: fatty acids and inflammation-from the membrane to the nucleus and from the laboratory bench to the clinic. Clin Nutr. (2010) 29:5-12. doi: 10.1016/j.clnu.2009.11.003

72. Wright SA, O'Prey FM, McHenry MT, Leahey WJ, Devine AB, Duffy EM, et al. A randomised interventional trial of $\omega$-3-polyunsaturated fatty acids on endothelial function and disease activity in systemic lupus erythematosus. Ann Rheum Dis. (2008) 67:841-8. doi: 10.1136/ard.2007.077156

73. Bello KJ, Fang H, Fazeli P, Bolad W, Corretti M, Magder LS, et al. Omega3 in SLE: a double-blind, placebo-controlled randomized clinical trial of endothelial dysfunction and disease activity in systemic lupus erythematosus. Rheumatol Int. (2013) 33:2789-96. doi: 10.1007/s00296-013-2811-3

74. Arriens C, Hynan LS, Lerman RH, Karp DR, Mohan C. Placebo-controlled randomized clinical trial of fish oil's impact on fatigue, quality of life, and disease activity in systemic lupus erythematosus. Nutr J. (2015) 14:8292. doi: 10.1186/s12937-015-0068-2

75. Partan RU, Hidayat R, Saputra N, Rahmayani F, Prapto H, Yudha TW. Seluang fish (rasbora spp.) oil decreases inflammatory cytokines via increasing vitamin D level in systemic lupus erythematosus. Open Access Maced J Med Sci. (2019) 7:1418-21. doi: 10.3889/oamjms.2019.308 
76. Bergamo P, Maurano F, Rossi M. Phase 2 enzyme induction by conjugated linoleic acid improves lupus-associated oxidative stress. Free Radic Biol Med. (2007) 43:71-9. doi: 10.1016/j.freeradbiomed.2007.03.023

77. Bergamo P, Luongo D, Maurano F, Mazzarella G, Stefanile R, Rossi M. Conjugated linoleic acid enhances glutathione synthesis and attenuates pathological signs in MRL/MpJ-Faslpr mice. J Lipid Res. (2006) 47:238291. doi: 10.1194/jlr.M600187-JLR200

78. Yang M, Cook ME. Dietary CLA decreased weight loss and extended survival following the onset of kidney failure in NZB/W F1 mice. Lipids. (2003) 38:21-4. doi: 10.1007/s11745-003-1026-8

79. Aparicio-Soto M, Sanchez-Hidalgo M, Cárdeno A, Rosillo MÁ, SanchezFidalgo S, Utrilla J, et al. Dietary extra virgin olive oil attenuates kidney injury in pristane-induced SLE model via activation of HO-1/Nrf-2 antioxidant pathway and suppression of JAK/STAT, NF-кB and MAPK activation. J Nutr Biochem. (2016) 27:278-88. doi: 10.1016/j.jnutbio.2015.09.017

80. Pocovi-Gerardino G, Correa-Rodríguez M, Callejas-Rubio JL, RíosFernández R, Martín-Amada M, Cruz-Caparros MG, et al. Dietary inflammatory index score and cardiovascular disease risk markers in women with systemic lupus erythematosus. J Acad Nutr Diet. (2019) 120:2807. doi: 10.1016/j.jand.2019.06.007

81. Charoenwoodhipong P, Harlow SD, Marder W, Hassett AL, McCune WJ, Gordon C, et al. Dietary omega polyunsaturated fatty acid intake and patientreported outcomes in systemic lupus erythematosus: the michigan lupus epidemiology \& surveillance (MILES) program. Arthritis Care Res. (2019) 72:874-81. doi: 10.1002/acr.23925

82. Patrick RP, Ames BN. Vitamin D and the omega-3 fatty acids control serotonin synthesis and action, part 2: relevance for ADHD, bipolar disorder, schizophrenia, and impulsive behavior. FASEB J. (2015) 29:220722. doi: 10.1096/fj.14-268342

83. Fenton JI, Hord NG, Ghosh S, Gurzell EA. Immunomodulation by dietary long chain omega-3 fatty acids and the potential for adverse health outcomes. Prostaglandins Leukot Essent Fatty Acids. (2013) 89:37990. doi: 10.1016/j.plefa.2013.09.011

84. Yang M, Pariza MW, Cook ME. Dietary conjugated linoleic acid protects against end stage disease of systemic lupus erythematosus in the NZB/W F1 mouse. Immunopharmacol Immunotoxicol. (2000) 22:43349. doi: 10.3109/08923970009026004

85. Benjamin S, Prakasan P, Sreedharan S, Wright ADG, Spener F. Pros and cons of CLA consumption: an insight from clinical evidences. Nutr Metab. (2015) 12:4-23. doi: 10.1186/1743-7075-12-4

86. Jones JM. CODEX-aligned dietary fiber definitions help to bridge the 'fiber gap'. Nutr J. (2014) 13:34. doi: 10.1186/1475-2891-13-34

87. Makki K, Deehan EC, Walter J, Bäckhed F. The impact of dietary fiber on gut microbiota in host health and disease. Cell Host Microbe. (2018) 23:705-15. doi: 10.1016/j.chom.2018.05.012

88. Statovci D, Aguilera M, MacSharry J, Melgar S. The impact of western diet and nutrients on the microbiota and immune response at mucosal interfaces. Front Immunol. (2017) 8:838. doi: 10.3389/fimmu.2017.00838

89. Wu GD, Chen J, Hoffmann C, Bittinger K, Chen YY, Keilbaugh SA, et al. Linking long-term dietary patterns with gut microbial enterotypes. Science. (2011) 334:105-8. doi: 10.1126/science.1208344

90. Kong LC, Holmes BA, Cotillard A, Habi-Rachedi F, Brazeilles R, Gougis $S$, et al. Dietary patterns differently associate with inflammation and gut microbiota in overweight and obese subjects. PLoS ONE. (2014) 9:e109434. doi: 10.1371/journal.pone.0109434

91. Kim M, Qie Y, Park J, Kim CH. Gut microbial metabolites fuel host antibody responses. Cell Host Microbe. (2016) 20:202-14. doi: 10.1016/j.chom.2016.07.001

92. Bishehsari F, Engen P, Preite N, Tuncil Y, Naqib A, Shaikh M, et al. Dietary fiber treatment corrects the composition of gut microbiota, promotes SCFA production, and suppresses colon carcinogenesis. Genes. (2018) 9:117. doi: 10.3390/genes 9020102

93. Silverman GJ, Azzouz DF, Alekseyenko AV. Systemic lupus erythematosus and dysbiosis in the microbiome: cause or effect or both? Curr Opin Immunol. (2019) 61:80-5. doi: 10.1016/j.coi.2019.08.007

94. López P, Sánchez B, Margolles A, Suárez A. Intestinal dysbiosis in systemic lupus erythematosus: cause or consequence? Curr Opin Rheumatol. (2016) 28:515-22. doi: 10.1097/BOR.0000000000000309
95. Hevia A, Milani C, López P, Cuervo A, Arboleya S, Duranti S, et al. Intestinal dysbiosis associated with systemic lupus erythematosus. MBio. (2014) 5:114. doi: $10.1128 / \mathrm{mBio} .01548-14$

96. He Z, Shao T, Li H, Xie Z, Wen C. Alterations of the gut microbiome in Chinese patients with systemic lupus erythematosus. Gut Pathog. (2016) 8:1-7. doi: 10.1186/s13099-016-0146-9

97. Rodríguez-Carrio J, López P, Sánchez B, González S, Gueimonde M, Margolles A, et al. Intestinal dysbiosis is associated with altered short-chain fatty acids and serum-free fatty acids in systemic lupus erythematosus. Front Immunol. (2017) 8:23. doi: 10.3389/fimmu.2017.00023

98. Minami Y, Hirabayashi Y, Nagata C, Ishii T, Harigae H, Sasaki T. Intakes of vitamin B6 and dietary fiber and clinical course of systemic lupus erythematosus: a prospective study of Japanese female patients. J Epidemiol. (2011) 21:246-54. doi: 10.2188/jea.JE20100157

99. Gernand AD, Schulze KJ, Stewart CP, West KP Jr, Christian P. Micronutrient deficiencies in pregnancy worldwide: health effects and prevention. Nat Rev Endocrinol. (2016) 12:274-89. doi: 10.1038/nrendo.2016.37

100. Liao X, Ren J, Wei CH, Ross AC, Cecere TE, Jortner BS, et al. Paradoxical effects of all-trans-retinoic acid on lupus-like disease in the MRL/lpr mouse model. PLoS ONE. (2015) 10:e0118176. doi: 10.1371/journal.pone.0118176

101. Liao CH, Erdman J Jr, Voss E Jr, Johnston P. Dietary vitamin A deficiency and the immune system in a murine model of systemic lupus erythematosus. Nutr Res. (1996) 16:279-92. doi: 10.1016/0271-5317(96)00012-7

102. Ikeda T, Nishide T, Ohtani T, Furukawa F. The effects of vitamin A derivative etretinate on the skin of MRL mice. Lupus. (2005) 14:5106. doi: 10.1191/0961203305lu2144oa

103. Kinoshita K, Kishimoto K, Shimazu H, Nozaki Y, Sugiyama M, Ikoma S, et al. Successful treatment with retinoids in patients with lupus nephritis. Am J Kidney Dis. (2010) 55:344-7. doi: 10.1053/j.ajkd.2009.06.012

104. Vien C, González-Cabello R, Bodó I, Gergely P. Effect of vitamin A treatment on the immune reactivity of patients with systemic lupus erythematosus. $J$ Clin Lab Immunol. (1988) 26:33-5.

105. Handono K, Firdausi SN, Pratama MZ, Endharti AT, Kalim H. Vitamin A improve Th17 and Treg regulation in systemic lupus erythematosus. Clin Rheumatol. (2016) 35:631-8. doi: 10.1007/s10067-016-3197-x

106. Sun LD, Zeng K, Wang Q. Study of riboflavin nutritional status in patients with systemic lupus erythematosus. Mod Prev Med. (2007) 1:53-5.

107. Molad Y, Rachmilewitz B, Sidi Y, Pinkhas J, Weinberger A. Serum cobalamin and transcobalamin levels in systemic lupus erythematosus. Am J Med. (1990) 88:141-4. doi: 10.1016/0002-9343(90)90463-N

108. Varghese B, Haase N, Low PS. Depletion of folate-receptor-positive macrophages leads to alleviation of symptoms and prolonged survival in two murine models of systemic lupus erythematosus. Mol Pharm. (2007) 4:679-85. doi: 10.1021/mp0700615

109. Minami Y, Sasaki T, Arai Y, Kurisu Y, Hisamichi S. Diet and systemic lupus erythematosus: a 4 year prospective study of Japanese patients. J Rheumatol. (2003) 30:747-54.

110. Tam LS, Li EK, Leung VY, Griffith JF, Benzie IF, Lim PL, et al. Effects of vitamins $\mathrm{C}$ and $\mathrm{E}$ on oxidative stress markers and endothelial function in patients with systemic lupus erythematosus: a double blind, placebo controlled pilot study. J Rheumatol. (2005) 32:275-82.

111. Lai YH, Fang TC. The pleiotropic effect of vitamin D. ISRN Nephrol. (2013) 2013:898125. doi: 10.5402/2013/898125

112. Dankers W, Colin EM, van Hamburg JP, Lubberts E. Vitamin $\mathrm{D}$ in autoimmunity: molecular mechanisms and therapeutic potential. Front Immunol. (2017) 7:697. doi: 10.3389/fimmu.2016. 00697

113. Mok CC. Vitamin D and systemic lupus erythematosus: an update. Expert Rev Clin Immunol. (2013) 9:453-63. doi: 10.1586/eci.13.19

114. Damanhouri LH. Vitamin D deficiency in Saudi patients with systemic lupus erythematosus. Saudi Med J. (2009) 30:1291-5.

115. Farid E, Jaradat A, Al-Segai O, Hassan A. Prevalence of vitamin D deficiency in adult patients with systemic lupus erythematosus in Kingdom of Bahrain. Egypt J Immunol. (2017) 24:1-8.

116. Willis R, Smikle M, DeCeulaer K, Romay-Penabad Z, Papalardo E, Jajoria $\mathrm{P}$, et al. Clinical associations of proinflammatory cytokines, oxidative biomarkers and vitamin D levels in systemic lupus erythematosus. Lupus. (2017) 26:1517-27. doi: 10.1177/0961203317706557 
117. Kamen DL, Cooper GS, Bouali H, Shaftman SR, Hollis BW, Gilkeson GS. Vitamin D deficiency in systemic lupus erythematosus. Autoimmun Rev. (2006) 5:114-7. doi: 10.1016/j.autrev.2005.05.009

118. Toloza SM, Cole DE, Gladman DD, Ibanez D, Urowitz MB. Vitamin D insufficiency in a large female SLE cohort. Lupus. (2010) 19:139. doi: 10.1177/0961203309345775

119. McGhie TK, DeCeulaer K, Walters CA, Soyibo A, Lee MG. Vitamin D levels in Jamaican patients with systemic lupus erythematosus. Lupus. (2014) 23:1092-6. doi: 10.1177/0961203314528556

120. Souto M, Coelho A, Guo C, Mendonca L, Argolo S, Papi J, et al. Vitamin D insufficiency in Brazilian patients with SLE: prevalence, associated factors, and relationship with activity. Lupus. (2011) 20:101926. doi: 10.1177/0961203311401457

121. Schoindre Y, Jallouli M, Tanguy ML, Ghillani P, Galicier L, Aumaitre O, et al. Lower vitamin D levels are associated with higher systemic lupus erythematosus activity, but not predictive of disease flare-up. Lupus Sci Med. (2014) 1:1-7. doi: 10.1136/lupus-2014-000027

122. Szodoray P, Tarr T, Bazso A, Poor G, Szegedi G, Kiss E. The immunopathological role of vitamin D in patients with SLE: data from a single centre registry in Hungary. Scand J Rheumatol. (2011) 40:1226. doi: 10.3109/03009742.2010.507220

123. Muller K, Kriegbaum NJ, Baslund B, Sorensen OH, Thymann M, Bentzen K. Vitamin D3 metabolism in patients with rheumatic diseases: low serum levels of 25-hydroxyvitamin D3 in patients with systemic lupus erythematosus. Clin Rheumatol. (1995) 14:397-400. doi: 10.1007/BF02207671

124. Salman-Monte TC, Torrente-Segarra V, Almirall M, Corzo P, Mojal S, Carbonell-Abelló J. Prevalence and predictors of vitamin D insufficiency in supplemented and non-supplemented women with systemic lupus erythematosus in the Mediterranean region. Rheumatol Int. (2016) 36:97585. doi: 10.1007/s00296-016-3497-0

125. Munoz-Ortego J, Torrente-Segarra V, Prieto-Alhambra D, Salman-Monte TC, Carbonell-Abello J. Prevalence and predictors of vitamin D deficiency in non-supplemented women with systemic lupus erythematosus in the Mediterranean region: a cohort study. Scand J Rheumatol. (2012) 41:4725. doi: 10.3109/03009742.2012.697189

126. Yeap SS, Othman AZ, Zain AA, Chan SP. Vitamin D levels: its relationship to bone mineral density response and disease activity in premenopausal Malaysian systemic lupus erythematosus patients on corticosteroids. Int J Rheum Dis. (2012) 15:17-24. doi: 10.1111/j.1756-185X.2011.01653.x

127. Lin TC, Wu JY, Kuo ML, Ou LS, Yeh KW, Huang JL. Correlation between disease activity of pediatric-onset systemic lupus erythematosus and level of vitamin D in Taiwan: a case-cohort study. J Microbiol Immunol Infect. (2018) 51:110-4. doi: 10.1016/j.jmii.2015.12.005

128. Sumethkul K, Boonyaratavej S, Kitumnuaypong T, Angthararuk $S$, Cheewasat $P$, Manadee $\mathrm{N}$, et al. The predictive factors of low serum 25-hydroxyvitamin $\mathrm{D}$ and vitamin $\mathrm{D}$ deficiency in patients with systemic lupus erythematosus. Rheumatol Int. (2013) 33:1461-7. doi: 10.1007/s00296-012-2537-7

129. Mandal M, Tripathy R, Panda AK, Pattanaik SS, Dakua S, Pradhan AK, et al. Vitamin D levels in Indian systemic lupus erythematosus patients: association with disease activity index and interferon alpha. Arthritis Res Ther. (2014) 16:1-8. doi: 10.1186/ar4479

130. Abdel Galil SM, El-Shafey AM, Abdul-Maksoud RS, El-Boshy M. Interferon alpha gene expression and serum level association with low vitamin D levels in Egyptian female patients with systemic lupus erythematosus. Lupus. (2018) 27:199-209. doi: 10.1177/0961203317716321

131. Hamza RT, Awwad KS, Ali MK, Hamed AI. Reduced serum concentrations of 25-hydroxy vitamin D in Egyptian patients with systemic lupus erythematosus: relation to disease activity. Med Sci Monit. (2011) 17:7118. doi: 10.12659/MSM.882131

132. AlSaleem A, AlSaghier A, Al-Mayouf SM. Vitamin D status in children with systemic lupus erythematosus and its association with clinical and laboratory parameters. Clin Rheumatol. (2015) 34:81-4. doi: 10.1007/s10067-014-2811-z

133. Eloi M, Horvath DV, Ortega JC, Prado MS, Andrade LEC, Szejnfeld VL, et al. 25-Hydroxivitamin D serum concentration, not free and bioavailable vitamin D, is associated with disease activity in systemic lupus erythematosus patients. PLoS ONE. (2017) 12:e0170323. doi: 10.1371/journal.pone.0170323
134. Borba VZ, Vieira JG, Kasamatsu T, Radominski SC, Sato EI, Lazaretti-Castro M. Vitamin D deficiency in patients with active systemic lupus erythematosus. Osteoporos Int. (2009) 20:427-33. doi: 10.1007/s00198-008-0676-1

135. Yap K, Northcott M, Hoi AB, Morand E, Nikpour M. Association of low vitamin $\mathrm{D}$ with high disease activity in an Australian systemic lupus erythematosus cohort. Lupus Sci Med. (2015) 2:1-6. doi: 10.1136/lupus-2014-000064

136. Robinson AB, Tangpricha V, Yow E, Gurion R, McComsey GA, Schanberg LE. Vitamin D deficiency is common and associated with increased Creactive protein in children and young adults with lupus: an atherosclerosis prevention in pediatric lupus erythematosus substudy. Lupus Sci Med. (2014) 1:1-7. doi: 10.1136/lupus-2014-000011

137. Gao C, Liu S, Wu Z, Li T, Gao G, Liu Z, et al. Severe vitamin D deficiency increases the risk for moderate to severe disease activity in Chinese patients with SLE. Lupus. (2016) 25:1224-9. doi: 10.1177/0961203316635289

138. Miskovic R, Plavsic A, Raskovic S, Jovicic Z, Bolpacic J. Vitamin D status in patients with systemic lupus erythematosus in Serbia: correlation with disease activity and clinical manifestations. Open Access Maced J Med Sci. (2015) 3:256-61. doi: 10.3889/oamjms.2015.052

139. Hiraki LT, Munger KL, Costenbader KH, Karlson EW. Dietary intake of vitamin D during adolescence and risk of adult-onset systemic lupus erythematosus and rheumatoid arthritis. Arthritis Care Res. (2012) 64:182936. doi: 10.1002/acr.21776

140. Costenbader KH, Feskanich D, Holmes M, Karlson EW, BenitoGarcia E. Vitamin D intake and risks of systemic lupus erythematosus and rheumatoid arthritis in women. Ann Rheum Dis. (2008) 67:530-5. doi: 10.1136/ard.2007.072736

141. Yu Q, Qiao Y, Liu D, Liu F, Gao C, Duan J, et al. Vitamin D protects podocytes from autoantibodies induced injury in lupus nephritis by reducing aberrant autophagy. Arthritis Res Ther. (2019) 21:1930. doi: 10.1186/s13075-018-1803-9

142. Lima G, Paupitz J, Aikawa N, Alvarenga J, Pereira RR. A randomized double-blind placebo-controlled trial of vitamin D supplementation in juvenile-onset systemic lupus erythematosus: positive effect on trabecular microarchitecture using HR-pQCT. Osteoporos Int. (2018) 29:587-94. doi: 10.1007/s00198-017-4316-5

143. Sun LY, Zhang HY, Feng XB, Hou YY, Lu LW, Fan LM. Abnormality of bone marrow-derived mesenchymal stem cells in patients with systemic lupus erythematosus. Lupus. (2007) 16:121-8. doi: 10.1177/0961203306075793

144. Xu JJ, Sun YB, Zhang XL, Wang XF. Vitamin D analog EB1089 could repair the defective bone marrow-derived mesenchymal stromal cells in patients with systemic lupus erythematosus. Int J Clin Exp Med. (2015) 8:916-21.

145. Garf KE, Marzouk H, Farag Y, Rasheed L, El Garf A. Vitamin D status in Egyptian patients with juvenile-onset systemic lupus erythematosus. Rheumatol Int. (2015) 35:1535-40. doi: 10.1007/s00296-015-3245-x

146. Lima G, Paupitz J, Aikawa NE, Takayama L, Bonfa E, Pereira RM. Vitamin $\mathrm{D}$ supplementation in adolescents and young adults with juvenile systemic lupus erythematosus for improvement in disease activity and fatigue scores: a randomized, double-blind, placebo-controlled trial. Arthritis Care Res. (2016) 68:91-8. doi: 10.1002/acr.22621

147. Islam MA, Khandker SS, Alam SS, Kotyla P, Hassan R. Vitamin $\mathrm{D}$ status in patients with systemic lupus erythematosus (SLE): a systematic review and meta-analysis. Autoimmun Rev. (2019) 18:119. doi: 10.1016/j.autrev.2019.102392

148. Zheng R, Gonzalez A, Yue J, Wu X, Qiu M, Gui L, et al. Efficacy and safety of vitamin $\mathrm{D}$ supplementation in patients with systemic lupus erythematosus: a meta-analysis of randomized controlled trials. Am J Med Sci. (2019) 358:104-14. doi: 10.1016/j.amjms.2019.04.020

149. Zhao M, Duan XH, Wu ZZ, Gao CC, Wang N, Zheng ZH. Severe vitamin D deficiency affects the expression of autophagy related genes in PBMCs and Tcell subsets in active systemic lupus erythematosus. Am J Clin Exp Immunol. (2017) 6:43-51.

150. Yazdanpanah E, Mahmoudi M, Sahebari M, Rezaieyazdi Z, Esmaeili SA, Tabasi N, et al. Vitamin D3 alters the expression of toll-like receptors in peripheral blood mononuclear cells of patients with systemic lupus erythematosus. J Cell Biochem. (2017) 118:4831-5. doi: 10.1002/jcb. 26155 
151. Marinho A, Carvalho C, Boleixa D, Bettencourt A, Leal B, Guimarães J, et al. Vitamin D supplementation effects on FoxP3 expression in $\mathrm{T}$ cells and FoxP3+/IL-17A ratio and clinical course in systemic lupus erythematosus patients: a study in a Portuguese cohort. Immunol Res. (2017) 65:197206. doi: 10.1007/s12026-016-8829-3

152. Ritterhouse LL, Crowe SR, Niewold TB, Kamen DL, Macwana SR, Roberts VC, et al. Vitamin D deficiency is associated with an increased autoimmune response in healthy individuals and in patients with systemic lupus erythematosus. Ann Rheum Dis. (2011) 70:1569-74. doi: 10.1136/ard.2010.148494

153. Kokic V, Martinovic Kaliterna D, Radic M, Perkovic D, Cvek M, Capkun V. Relationship between vitamin D, IFN- $\gamma$, and E2 levels in systemic lupus erythematosus. Lupus. (2016) 25:282-8. doi: 10.1177/0961203315605367

154. Reynolds JA, Rosenberg AZ, Smith CK, Sergeant JC, Rice GI, Briggs TA, et al. Brief report: vitamin D deficiency is associated with endothelial dysfunction and increases type I interferon gene expression in a murine model of systemic lupus erythematosus. Arthritis rheumatol. (2016) 68:292935. doi: 10.1002/art.39803

155. Reynolds JA, Haque S, Williamson K, Ray DW, Alexander MY, Bruce IN. Vitamin D improves endothelial dysfunction and restores myeloid angiogenic cell function via reduced CXCL-10 expression in systemic lupus erythematosus. Sci Rep. (2016) 6:1-11. doi: 10.1038/srep22341

156. Handono K, Sidarta YO, Pradana BA, Nugroho RA, Hartono IA, Kalim $\mathrm{H}$, et al. Vitamin D prevents endothelial damage induced by increased neutrophil extracellular traps formation in patients with systemic lupus erythematosus. Acta Med Indones. (2014) 46:189-98.

157. Schneider L, Colar da Silva A, Werres Junior L, Alegretti A, dos Santos AP, Santos M, et al. Vitamin D levels and cytokine profiles in patients with systemic lupus erythematosus. Lupus. (2015) 24:11917. doi: $10.1177 / 0961203315584811$

158. Piantoni S, Andreoli L, Scarsi M, Zanola A, Dall'Ara F, Pizzorni C, et al. Phenotype modifications of T-cells and their shift toward a Th2 response in patients with systemic lupus erythematosus supplemented with different monthly regimens of vitamin D. Lupus. (2015) 24:4908. doi: $10.1177 / 0961203314559090$

159. Handono K, Marisa D, Kalim H. Association between the low levels of vitamin $\mathrm{D}$ and Treg function in systemic lupus erythematosus patients. Acta Med Indones. (2013) 45:26-31.

160. Ding Y, Liao W, He XJ, Xiang W. Effects of 1, $25(\mathrm{OH}) 2 \mathrm{D} 3$ and vitamin $\mathrm{D}$ receptor on peripheral CD4+/CD8+ double-positive $\mathrm{T}$ lymphocytes in a mouse model of systemic lupus erythematosus. J Cell Mol Med. (2017) 21:975-85. doi: $10.1111 / \mathrm{jcmm} .13037$

161. He XJ, Ding Y, Xiang W, Dang XQ. Roles of 1, $25(\mathrm{OH}) 2 \mathrm{D} 3$ and vitamin $\mathrm{D}$ receptor in the pathogenesis of rheumatoid arthritis and systemic lupus erythematosus by regulating the activation of $\mathrm{CD} 4+\mathrm{T}$ cells and the PKC /ERK signaling pathway. Cell Physiol Biochem. (2016) 40:74356. doi: $10.1159 / 000453135$

162. Terrier B, Derian N, Schoindre Y, Chaara W, Geri G, Zahr N, et al. Restoration of regulatory and effector $\mathrm{T}$ cell balance and $\mathrm{B}$ cell homeostasis in systemic lupus erythematosus patients through vitamin D supplementation. Arthritis Res Ther. (2012) 14:1-10. doi: 10.1186/ar4060

163. Chen DJ, Li LJ, Yang XK, Yu T, Leng RX, Pan HF, et al. Altered microRNAs expression in T cells of patients with SLE involved in the lack of vitamin D. Oncotarget. (2017) 8:62099-110. doi: 10.18632/oncotarget.19062

164. Hsieh CC, Lin BF. The effects of vitamin E supplementation on autoimmuneprone New Zealand black $\times$ New Zealand white F1 mice fed an oxidised oil diet. Br J Nutr. (2005) 93:655-62. doi: 10.1079/BJN20051413

165. Hsieh CC, Lin BF. Opposite effects of low and high dose supplementation of vitamin E on survival of MRL/lpr mice. Nutrition. (2005) 21:9408. doi: 10.1016/j.nut.2004.11.021

166. Comstock G, Burke A, Hoffman S, Helzlsouer K, Bendich A, Masi A, et al. Serum concentrations of $\alpha$ tocopherol, $\beta$ carotene, and retinol preceding the diagnosis of rheumatoid arthritis and systemic lupus erythematosus. Ann Rheum Dis. (1997) 56:323-5. doi: 10.1136/ard.56.5.323

167. Maeshima E, Liang XM, Goda M, Otani H, Mune M. The efficacy of vitamin $\mathrm{E}$ against oxidative damage and autoantibody production in systemic lupus erythematosus: a preliminary study. Clin Rheumatol. (2007) 26:4014. doi: $10.1007 / \mathrm{s} 10067-006-0477-\mathrm{x}$
168. Shahba A, Esheba NE, Fooda AA, El-Dardiry S, Wagih A, el-Deeb O. Effect of nigella sativa and vitamin $\mathrm{E}$ on some oxidative/nitrosative biomarkers in systemic lupus erythematosus patients. Life Sci J. (2015) 12:157-62.

169. Mellor-Pita S, Tutor-Ureta P, Rosado S, Alkadi K, Granado F, Jimenez-Ortiz C, et al. Calcium and vitamin D supplement intake may increase arterial stiffness in systemic lupus erythematosus patients. Clin Rheumatol. (2019) 38:1-10. doi: 10.1007/s10067-018-04416-x

170. Al-Kushi AG, Azzeh FS, Header EA, ElSawy NA, Hijazi HH, Jazar AS, et al. Effect of vitamin D and calcium supplementation in patients with systemic lupus erythematosus. Saudi J Med Med Sci. (2018) 6:13742. doi: 10.4103/sjmms.sjmms_134_17

171. Tayel MY, El-Zawawy AI, Said MI, Soliman EA, Mohamed MK. A study on the role of calcium homeostasis and vitamin D deficiency in premenopausal systemic lupus erythematosus patients and its relation with disease activity. Egypt J Obes Diabetes Endocrinol. (2016) 2:95107. doi: $10.4103 / 2356-8062.197571$

172. Deluca HF, Cantorna MT. Vitamin D: its role and uses in immunology. FASEB J. (2001) 15:2579-85. doi: 10.1096/fj.01-0433rev

173. Leiba A, Amital H, Gershwin M, Shoenfeld Y. Diet and lupus. Lupus. (2001) 10:246-8. doi: 10.1191/096120301674681790

174. Beach R, Gershwin ME, Hurley L. Nutritional factors and autoimmunity. II. prolongation of survival in zinc-deprived NZB/W mice. J Immunol. (1982) 128:308-13.

175. Kretzschmar P, Brewer G, Walker S. Depot-zinc therapy of systemic lupus erythematosus in B/W mice. Proc Soc Exp Biol Med. (1981) 168:3015. doi: 10.3181/00379727-168-41276

176. Vitales-Noyola M, Layseca-Espinosa E, Baranda L, Abud-Mendoza C, NiñoMoreno P, Monsiváis-Urenda A, et al. Analysis of sodium chloride intake and Treg/Th17 lymphocytes in healthy individuals and patients with rheumatoid arthritis or systemic lupus erythematosus. J Immunol Res. (2018) 2018:112. doi: $10.1155 / 2018 / 9627806$

177. Scrivo R, Massaro L, Barbati C, Vomero M, Ceccarelli F, Spinelli FR, et al. The role of dietary sodium intake on the modulation of $\mathrm{T}$ helper 17 cells and regulatory $\mathrm{T}$ cells in patients with rheumatoid arthritis and systemic lupus erythematosus. PLoS ONE. (2017) 12:114. doi: 10.1371/journal.pone.0184449

178. Yang X, Yao G, Chen W, Tang X, Feng X, Sun L. Exacerbation of lupus nephritis by high sodium chloride related to activation of SGK1 pathway. Int Immunopharmacol. (2015) 29:568-73. doi: 10.1016/j.intimp.2015.09.027

179. Soni C, Sinha I, Fasnacht MJ, Olsen NJ, Rahman ZS, Sinha R. Selenium supplementation suppresses immunological and serological features of lupus in B6. Sle1b mice. Autoimmunity. (2019) 52:5768. doi: 10.1080/08916934.2019.1603297

180. O'Dell J, McGivern JP, Kay H, Klassen L. Improved survival in murine lupus as the result of selenium supplementation. Clin Exp Immunol. (1988) 73:3227.

181. Leiter LM, Reuhl KR, Racis Jr SP, Sherman AR. Iron status alters murine systemic lupus erythematosus. J Nutr. (1995) 125:474-84.

182. Duffy EM, Meenagh GK, McMillan SA, Strain JJ, Hannigan BM, Bell AL. The clinical effect of dietary supplementation with omega-3 fish oils and/or copper in systemic lupus erythematosus. J Rheumatol. (2004) 31:1551-6.

183. Zhao J, Wang J, Zhou M, Li M, Li M, Tan H. Curcumin attenuates murine lupus via inhibiting NLRP3 inflammasome. Int Immunopharmacol. (2019) 69:213-6. doi: 10.1016/j.intimp.2019.01.046

184. Foxley S, Zamora M, Hack B, Alexander RR, Roman B, Quigg RJ, et al. Curcumin aggravates CNS pathology in experimental systemic lupus erythematosus. Brain Res. (2013) 1504:85-96. doi: 10.1016/j.brainres.2013.01.040

185. Lee H, Kim H, Lee G, Chung HS, Bae H. Curcumin attenuates lupus nephritis upon interaction with regulatory $\mathrm{T}$ cells in New Zealand Black/White mice. Br J Nutr. (2013) 110:69-76. doi: 10.1017/S0007114512004734

186. Singgih Wahono C, Diah Setyorini C, Kalim H, Nurdiana N, Handono K. Effect of curcuma xanthorrhiza supplementation on systemic lupus erythematosus patients with hypovitamin $\mathrm{d}$ which were given Vitamin D3 towards Disease Activity (SLEDAI), IL-6, and TGF- $\beta 1$ serum. Int $J$ Rheumatol. (2017) 2017:1-9. doi: 10.1155/2017/7687053

187. Handono K, Pratama MZ, Endharti AT, Kalim H. Treatment of low doses curcumin could modulate Th17/Treg balance specifically on CD4+ T cell 
cultures of systemic lupus erythematosus patients. Cent Eur J Immunol. (2015) 40:461-9. doi: 10.5114/ceji.2015.56970

188. Wang M, Zhou G, Lv J, Zeng P, Guo C, Wang Q. Curcumin modulation of the activation of PYK2 in peripheral blood mononuclear cells from patients with lupus nephritis. Reumatologia. (2017) 55:26975. doi: $10.5114 /$ reum.2017.72623

189. Aparicio-Soto M, Montserrat-de la Paz S, Sanchez-Hidalgo M, Cardeno A, Bermudez B, Muriana FJ, et al. Virgin olive oil and its phenol fraction modulate monocyte/macrophage functionality: a potential therapeutic strategy in the treatment of systemic lupus erythematosus. Br J Nutr. (2018) 120:681-92. doi: 10.1017/S0007114518001976

190. Tsai PY, Ka SM, Chang JM, Chen HC, Shui HA, Li CY, et al. Epigallocatechin-3-gallate prevents lupus nephritis development in mice via enhancing the Nrf2 antioxidant pathway and inhibiting NLRP3 inflammasome activation. Free Radic Biol Med. (2011) 51:744-54. doi: 10.1016/j.freeradbiomed.2011.05.016

191. Peairs A, Dai R, Gan L, Shimp S, Rylander MN, Li L, et al. Epigallocatechin-3gallate (EGCG) attenuates inflammation in MRL/lpr mouse mesangial cells. Cell Mol Immunol. (2010) 7:123-32. doi: 10.1038/cmi.2010.1

192. Aparicio-Soto M, Sánchéz-Hidalgo M, Cárdeno A, Lucena JM, GonzálézEscribano F, Castillo MJ, et al. The phenolic fraction of extra virgin olive oil modulates the activation and the inflammatory response of $\mathrm{T}$ cells from patients with systemic lupus erythematous and healthy donors. Mol Nutr Food Res. (2017) 61:1-9. doi: 10.1002/mnfr.201601080

193. Cuervo A, Hevia A, López P, Suárez A, Sánchez B, Margolles A, et al. Association of polyphenols from oranges and apples with specific intestinal microorganisms in systemic lupus erythematosus patients. Nutrients. (2015) 7:1301-17. doi: 10.3390/nu7021301

194. Han GM, Han XF. Lycopene reduces mortality in people with systemic lupus erythematosus: a pilot study based on the third national health and nutrition examination survey. J Dermatolog Treat. (2016) 27:4305. doi: 10.3109/09546634.2015.1133879

195. Kang HK, Ecklund D, Liu M, Datta SK. Apigenin, a non-mutagenic dietary flavonoid, suppresses lupus by inhibiting autoantigen presentation for expansion of autoreactive Th1 and Th17 cells. Arthritis Res Ther. (2009) 11:1-13. doi: 10.1186/ar2682

196. Pocovi-Gerardino G, Correa-Rodríguez M, Rubio JLC, Fernández RR, Ortego-Centeno N, Rueda-Medina B. Diet quality and high-sensitivity Creactive protein in patients with systemic lupus erythematosus. Biol Res Nurs. (2019) 21:107-13. doi: 10.1177/1099800418803176

197. Zahran AM, Elsayh KI, Saad K, Eloseily EM, Osman NS, Alblihed MA, et al. Effects of royal jelly supplementation on regulatory $\mathrm{T}$ cells in children with SLE. Food Nutr Res. (2016) 60:1-10. doi: 10.3402/fnr.v60. 32963

198. Mannoor M, Shimabukuro I, Tsukamotoa M, Watanabe H, Yamaguchi $\mathrm{K}$, Sato Y. Honeybee royal jelly inhibits autoimmunity in SLE-prone NZB $\times$ NZW F1 mice. Lupus. (2009) 18:44-52. doi: 10.1177/09612033080 94765

Conflict of Interest: The authors declare that the research was conducted in the absence of any commercial or financial relationships that could be construed as a potential conflict of interest.

Copyright $\odot 2020$ Islam, Khandker, Kotyla and Hassan. This is an open-access article distributed under the terms of the Creative Commons Attribution License (CC BY). The use, distribution or reproduction in other forums is permitted, provided the original author(s) and the copyright owner(s) are credited and that the original publication in this journal is cited, in accordance with accepted academic practice. No use, distribution or reproduction is permitted which does not comply with these terms. 